\title{
New remarkable Late Jurassic teleosts from southern Germany: Ascalaboidae n. fam., its content, morphology, and phylogenetic relationships
}

\author{
G. Arratia \\ Biodiversity Institute, University of Kansas, Dyche Hall, 1345 Jayhawk Blvd, Lawrence, Kansas 66045, USA \\ Correspondence to: G. Arratia (garratia@ ku.edu) \\ Received: 3 September 2015 - Revised: 6 December 2015 - Accepted: 9 December 2015 - Published: 18 January 2016
}

\begin{abstract}
Complete morphological descriptions, as preservation permits, are provided for a new Late Jurassic fish taxon (Ebertichthys ettlingensis n. gen. et n. sp.) and a revision of some morphological features of Ascalabos voithii Graf zu Münster from the Solnhofen limestones, southern Germany. A new family, Ascalaboidae, is erected to include the two species. The new family is supported by numerous synapomorphies, e.g., maxilla with external row of small conical teeth increasing in size posteriorly, absence of gular plate, low number of vertebrae (34 to 39), deep and narrow supracleithrum - deeper than opercle, and vertebral centrum formation of caudal region including paired chordacentra (pseudo-diplospondyly) that fuse in early ontogeny forming one chordacentrum that is later surrounded by an autocentrum. A phylogenetic analysis based on 173 characters and 42 taxa was performed. Following the phylogenetic hypothesis, the sister-group relationship [Ascalabos + Ebertichthys $]+$ more advanced teleosts stands above the node of Leptolepis coryphaenoides plus more advanced teleosts and below the node of Tharsis plus more advanced teleosts, and the new taxa are interpreted as extinct and primitive forms within Teleostei. The new genus and species is endemic and restricted to one Upper Jurassic locality - Ettling - whereas Ascalabos is known from different localities in the Solnhofen limestones, with the exception of Ettling.
\end{abstract}

\section{Introduction}

The fossiliferous localities of Bavaria, southern Germany, represent one of the richest fossil fish localities and one of the most extraordinary fossil Lagerstätte in the world (Arratia et al., 2015). They are a succession of Upper Jurassic localities (Kimmeridgian, Tithonian; Schweigert, 2015) with hundreds of nominal plant and animal species (Schultze, 2015, table 5). Unfortunately, as a common practice in the past, many of the museum specimens are identified as from "Solnhofen", without a precise locality.

Late Jurassic fishes of Bavaria have been known for over 200 years. The first illustrations appeared in the work of Knorr (1755: pl. 23: figs. 2, 3; pl. 26a: figs. 1-4; pl. 28: fig. 2; pl. 29: figs. 2-4). Later, fishes illustrated by Knorr were giving scientific names by de Blainville (1818). For further details see Arratia (1997) and Tischlinger and Viohl (2015). The publication from de Blainville (1818) opened the door to intensive research on fishes during the 19th century (e.g., Agassiz, 1833-1843; Graf zu Münster, 1834, 1839a, b, 1842; Wagner, 1861, 1863; Vetter, 1881; Woodward, 1895) that slowed down in the first half of the 20th century with few contributions, e.g., Eastman (1914), Biese (1927), and Weitzel (1933). After a gap in the study of Jurassic fossil fishes of the Solnhofen limestones, Nybelin $(1964,1967,1974)$ and Arratia $(1987 a, b)$ proposed fundamental changes to the taxonomy of teleosts from the region, and Taverne (1975a, b, 1981) and Patterson and Rosen (1977) provided additional morphological information of some of the teleostean species. Lambers (1992) listed 41 teleostean species, including pachycormiforms and aspidorhynchiforms. Since 1992 that number has increased to at least 62 nominal species (Schultze, 2015) and many others remain to be described.

Some of the new teleosts are known from a locality - Ettling - that was modestly explored during the last years of the 20th century. Its first known fossil was a fish (Orthogonikleithrus hoelli; Arratia, 1997), whose description was based 
on the 23 specimens recovered at that time. Now, the same species is known from thousands of specimens, and other species, most of them new, have been excavated and are currently under study. The first Jurassic crossognathiform from the Northern Hemisphere (Bavarichthys incognitus; Arratia and Tischlinger, 2010) and a new aspidorhynchiform (Aspidorhynchus sanzenbacheri; Brito and Ebert, 2009) are also known only from this locality. For a list of materials and species from Ettling, see Ebert et al. (2015).

The goal of this contribution is to describe a new fish family from the Solnhofen limestones that includes Ascalabos Graf zu Münster and a new genus and species. The phylogenetic position of the new family is studied and discussed.

\section{Materials and methods}

The specimens here described are listed under their corresponding descriptive sections. For a list of material used in the phylogenetic analysis, see Arratia (2013). Specimens here studied are deposited in the following institutions: CM, Carnegie Museum, Section of Vertebrate Paleontology, Pittsburg, Pennsylvania; CMMH, Cleveland Museum of Natural History, Cleveland, Ohio; JME ETT, Jura Museum Eichstätt, Bavaria (ETT indicates that the fish was collected in Ettling); JME SOS, Jura Museum Eichstätt, Bavaria (SOS indicates that the fish was collected at an unspecified locality in the Solnhofen limestones); NHM, Natural History Museum, London; and SMNH, Swedish Museum of Natural History, Department of Paleozoology, Stockholm.

Abrasive machines or chemicals were not used in the preparation of specimens from Ettling because of their fragile nature. All specimens studied herein were mechanically prepared.

The author, using Wild FM 8 and Leica MZ9 stereomicroscopes equipped with a camera lucida, prepared illustrations of the specimens. Thus, illustrations are based directly on specimens rather than on photographs. Photographs are not retouched with Photoshop. The latter was only used to label figures.

\subsection{Phylogenetic methodology}

The phylogenetic analysis was conducted using PAUP (Phylogenetic Analysis Using Parsimony) software (version 4.0b10) for 32 bit Microsoft (Swofford, 2000). The character matrix was constructed using MacClade for the analysis to run in PAUP. All characters are unweighted, unordered, and considered to be independent of one another. The phylogenetic analysis used the list of characters and coding of Arratia (2013) with the addition of seven new characters (Supplement 1). The outgroups used in the analysis are fossils and extant neopterygians, e.g., the basal parasemionotiform Watsonulus, the amiiforms Amia calva and A. pattersoni, and the lepisosteiforms Obaichthys and Lepisosteus. The data matrix with coding of characters is presented in Supplement 2.

\subsection{Anatomical terminology}

The terminology of the skull roof bones follows Westoll (1943), Jollie (1962), and Schultze (2008). This terminology is based on study of bones in Osteichthyes and differs from traditional skull roof terminology, which is fundamentally based on human anatomy and is not homologous. To avoid confusion, all figures show in square brackets the names of bones in the traditional terminology, e.g., parietal bone $[=$ frontal $]$ : pa $[=\mathrm{fr}]$. The terminology of the palatoquadrate and urohyal follows Arratia and Schultze (1990, 1991).

The structure of the vertebral column is one of the major sources of characters in the evolutionary history of holosteans and teleosts (Schultze and Arratia, 1989; Arratia et al., 2001). The term "vertebra" includes all serially repeated ossified, cartilaginous, and ligamentous elements around the notochord, consisting of the centrum, neural arch and spine, and haemal arch and spine (Schultze and Arratia, 1988; Arratia et al., 2001). Vertebrae formed by a single central element are called monospondylous, and those formed by more than one element are called diplospondylous (see Arratia et al., 2001, for further details). Mineralized or calcified portions that develop inside the fibrous sheath of the notochord or ossified portions that surround the notochord can form the centrum. The centrum is termed chordacentrum, arcocentrum, or autocentrum, depending on its origin and structure (Arratia et al., 2001, 103-106). These terms are used here in the descriptions of the vertebral centra and also in the lists of characters used in the phylogenetic analysis.

The terminology of the caudal endoskeletal elements (e.g., preural centrum, ural centrum, and parhypural) and of types of caudal skeletons (e.g., polyural or diural) follows Nybelin (1963), Schultze and Arratia (1986, 1989, 2013), and Arratia and Schultze (1992). "True" uroneurals are modified ural neural arches; "uroneural-like" elements are modified preural neural arches. These terms are included here in the phylogenetic analysis, and their usage follows Arratia and Lambers (1996) and Arratia and Schultze (2013). The terms fin rays, scutes, fulcra, procurrent rays, epaxial rudimentary rays, and principal rays follow definitions provided by Arratia $(2008,2009)$. A rudimentary ray, as defined by Arratia (2008), is a small ray with a short base not reaching endoskeletal bones. It is positioned between the epaxial basal fulcra and the first principal ray of the caudal fin. A rudimentary ray may be distally segmented or not. This interpretation of a rudimentary ray differs from that of Grande and Bemis (1998, figs. 84, 86).

The terminology of scales follows Schultze $(1966,1996)$. 


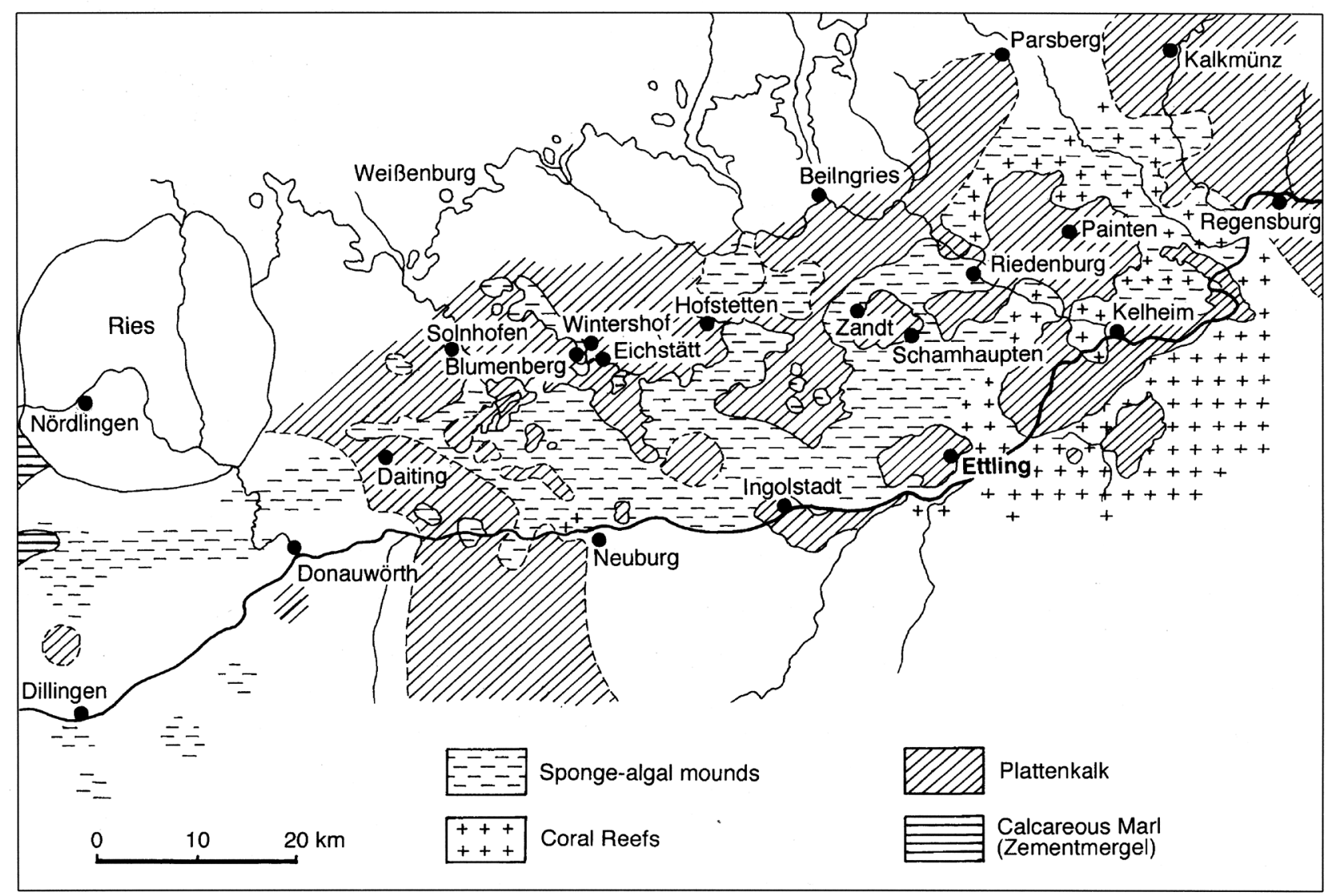

Figure 1. Distribution of Plattenkalk basins and reef areas in the southern Franconian Alb during the Early Tithonian (slightly modified from Viohl, 1996). The new fish described herein was recovered in Ettling.

\section{Systematic paleontology}

Actinopterygii Cope, 1887

Teleostei sensu Arratia, 1999

\section{Ascalaboidae n. fam.}

Diagnosis (based on a unique combination of characters; uniquely derived features among basal teleosts are identified with an asterisk [*]): Small teleosts of about $115 \mathrm{~mm}$ maximum length. Maxilla with external row of small conical teeth increasing in size posteriorly [*]. Supramaxilla 2 with a large, broad body and a narrow, long dorsoanterior process covering most of dorsal border of the long supramaxilla 1. Large, narrow opercle, almost 4 times deeper than subopercle. No gular plate. Low number of vertebrae, 34 to 39 [*]. Deep and narrow supracleithrum, deeper than opercle [*]. Vertebral centrum formation of caudal region including paired chordacentra (pseudo-diplospondyly) that fuse forming one chordacentrum that is later surrounded by an autocentrum [*]. Broad first dorsal pterygiophore with a peculiar fan-like shape with three or more anteroventral processes [*]. Preural ural centrum 1 and ural centrum 1 with short neural spines. High number of hypurals, nine or more. Six to eight uroneurals. Cycloid scales with circuli in anterior field and no radii.

Derivation of name: The family name derives from the genus name Ascalabos.

Content: Ascalabos voithii Graf zu Münster, $1839 \mathrm{~b}$ and Ebertichthys ettlingensis, $\mathrm{n}$. gen. et n. sp. (A few specimens preliminarily identify as Ascalabos-like have been recovered in Wattendorf and are in the process of being described. Another possible candidate is Anaethalion cirinensis Gaudant, 1968 from Cerin, France, which currently is under revision.) Geographical distribution and age: Southern Germany, Bavaria (Fig. 1). Upper Jurassic, Kimmeridgian (Wattendorf), Kimmeridgian-Lower Tithonian? (Ettling), and Tithonian (e.g., Eichstätt).

\section{Ebertichthys n. gen.}

Diagnosis (based on a unique combination of characters; uniquely derived features among primitive teleosts are identified with an asterisk [*]): Small teleosts of about $90 \mathrm{~mm}$ maximum length with dorsal-fin origin placed 
posterior to pelvic origin and equidistant to pelvic and anal fins [*]. Large head, about $33 \%$ of standard length [*]. Large eye, about $35 \%$ of head length [*]. Large, heavily ossified supraorbital bone, anteroventrally expanded. Large, elongate antorbital [*]. Infraorbital 1 long, narrow, and slightly broader anteriorly. Infraorbital 2 long and narrow, forming most of the ventral orbital margin [*]. Infraorbital 3 relatively small, leaving most of quadrate exposed [*]. Elongate ectopterygoid with a small tooth patch. Entopterygoid with small conical teeth. Triangular, narrow preopercle with ventral and posterior margins forming an angle of about $90^{\circ}$ [*]. Dorsal arm of preopercle almost reaching lateral margin of skull roof. Preopercle with an expanded, rounded flange at the level of infraorbital 3 [*]. Preopercular canal with elongate, narrow sensory tubules in ventral and dorsal arms. A massive, well-ossified cleithrum with dorsal arm shorter than ventral one [*]. First anal pterygiophore long, broadly expanded, and almost rectangular in shape [*]. Neural spine of preural centrum 1 shorter than neural spine of preural centrum 2. Ural centrum $1+2$ bearing two neural arches with short spines. Eight or nine hypurals. First three anterior uroneurals longer than posterior uroneurals 4 to 6 . Uroneural 1 extending anteriorly and reaching preural centrum 2. One "urodermal" present. Body covered with large cycloid scales.

Derivation of name: Ebertichthys is given in recognition of the dedicated work that Martin Ebert (Eichstätt) has done recently at Ettling, recovering fossil fishes and preparing them with the suffix - ichthys (Greek) for fish. M. Ebert collected the specimens described herein.

\section{Ebertichthys ettlingensis $\mathbf{n}$. sp.}

Figures 2-13

2008 Undescribed small teleost. - Ebert and Kölbl-Ebert, fig. 6.

2011 Ascalabos-like. - Ebert and Kölbl-Ebert, fig. 8.

2015 Teleost sp. 1. - Ebert et al., p. 21, fig. 13b; p. 22, fig. $14 \mathrm{a}$.

Diagnosis: Same as generic diagnosis.

Derivation of name: The specific name ettlingensis refers to the locality of Ettling and its rich and beautifully preserved fossils, from which the fishes were recovered.

Holotype: JME ETT 108a and 108b is preserved in part and counterpart. It is a complete, beautifully preserved specimen of about $75 \mathrm{~mm}$ total length including soft anatomy preservation (part of digestive system) and squamation (Fig. 2a). The specimen is heavily ossified, so that it is interpreted as an adult although the presence of unfused hypurals 1 and 2 and haemal arch of preural centrum 1 with their respective centrum.

Paratypes: JME ETT 11, JME ETT 24 (Fig. 2c), JME ETT 60, JME ETT 61, JME ETT 64a, JME ETT 132a, b (Fig. 2b), JME ETT 148, and JME ETT 847a.
Type locality and age: Ettling (Plattenkalks I-III), Bavaria (Arratia and Tischlinger, 2010; Ebert et al., 2015). Upper Jurassic, probably upper Kimmeridgian (Ebert et al., 2015) to lower Tithonian. However, the age of the locality is approximated due to the fact that well-preserved ammonoids have not been recovered.

Description

General description: The fish is small, below $90 \mathrm{~mm}$ total length, slightly fusiform, and with dorsal, pelvic, and anal fins producing a triangular outline, with the dorsal fin almost equidistant to the pelvic and anal fins (Fig. 2a-c). Dorsal fin insertion placed posterior to the midpoint of standard length (61 to $64 \%$ ). Pelvic fin insertion about at the midpoint of standard length (about 52 to $55 \%$ ). Anal fin insertion 69 to $73 \%$ of standard length (SL). Caudal peduncle deep, about half of the maximum body depth. The head is proportionally large, about $33 \%$ of standard length. In a young individual (JME ETT 61) of $34.7 \mathrm{~mm}$ total length, the head is comparatively larger (37\% of SL). Eye large, 34 to $36 \%$ of head length.

Skull roof and braincase: The skull roof is incompletely preserved or partially damaged in the studied specimens. Additionally, the skull is laterally compressed from burial, so that it is difficult to describe particular elements. All bones of the skull roof have smooth surfaces and are unornamented.

The main element of the skull roof (Fig. 3a-b) is the parietal bone (i.e., frontal bone of traditional terminology) that occupies most of the preorbital region and part of the postorbital region, which is short. The postorbital region is about one-third of the preorbital length. Anteriorly, the parietal bones suture with a broad and short mesethmoid (Figs. 3b and $4 \mathrm{~b}$ ). The latter bone presents two short and narrow lateral processes. Posteriorly, the mesethmoid sutures with the parietals throughout several interdigitating projections of different lengths. The parietals apparently leave a long, narrow space between them as a cranial fenestra, a condition that also has been observed in Ascalabos voithii (Arratia, 1997). A nasal bone is laterally placed to the anterior part of the parietal bone. The bone seems to be narrow and elongate, mainly carrying the anterior section of the supraorbital canal. Due to poor preservation, the limits between the parietal, postparietal, pterotic, and autosphenotic are not discernable, but the postparietal bones seem to be small and sutured to each other medially. The pterotic is very short and is the main element that articulates with the hyomandibula. The pterotic sutures with a small, triangular, and well-ossified autosphenotic anteriorly and with the parietal and postparietal medially. Its posterior region is covered by an elongate, narrow extrascapula. A short section of the middle pit line is observed, but it is unclear whether the pit line crossed the pterotic or not. The supraoccipital seems to be very small, with a very low crest. Boundaries between these bones (Fig. 3a-b) are difficult to discern due to the fragility and transparency of the bones.

Anteriorly and below the parietal, the autosphenotic sutures with a well-developed and ossified chondral bone, the 

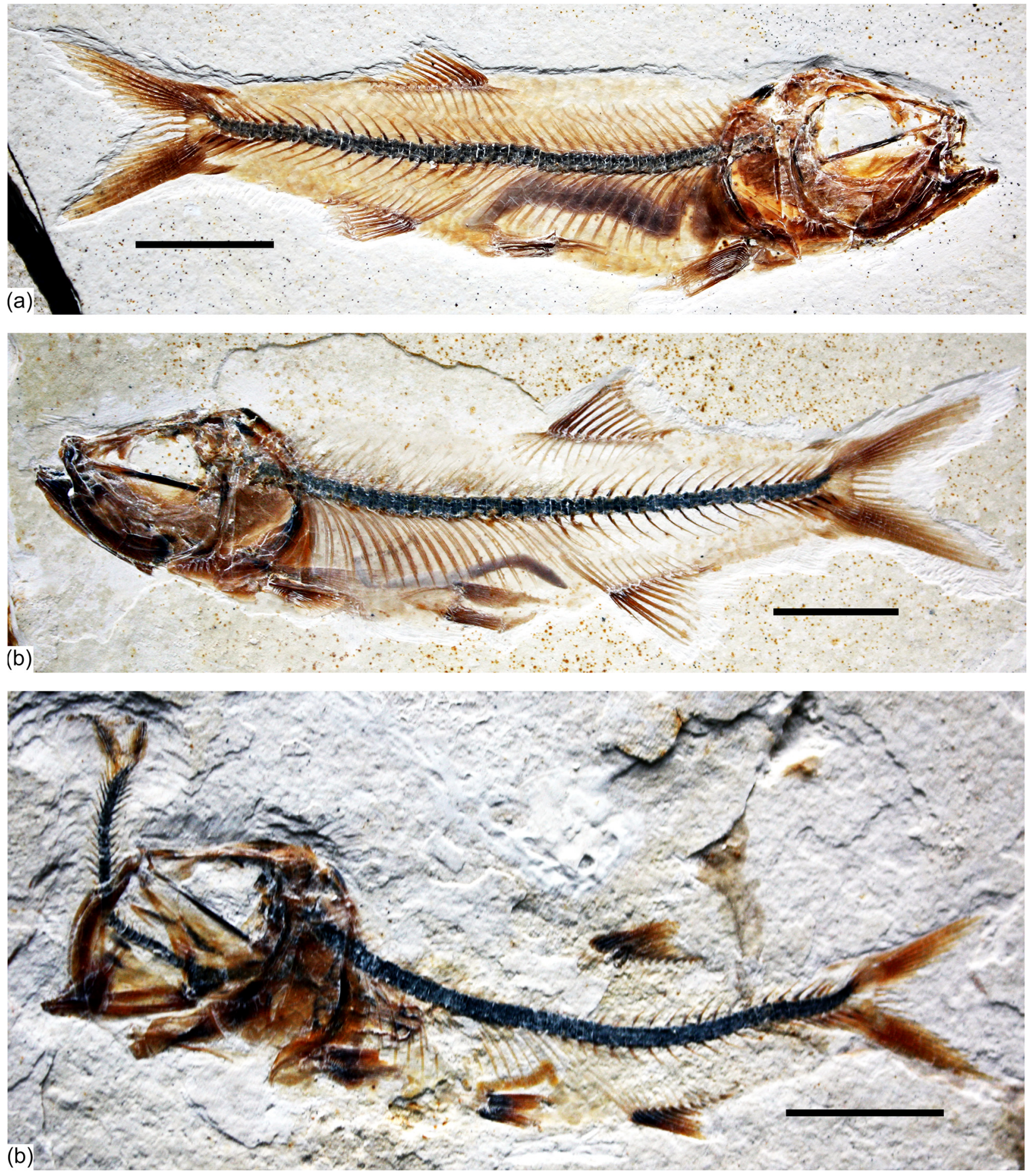

Figure 2. Ebertichthys ettlingensis n. gen. et n. sp. in lateral views. (a) Holotype JME ETT 108. (b) Paratype JME ETT 132a. (c) Paratype JME ETT 24, specimen with a fish prey in its mouth (small individual of Orthogonikleithrus). Scales equal $1 \mathrm{~cm}$. Photographs courtesy of M. Ebert.

pterosphenoid (Fig. 3b). Anterior to the pterosphenoid is another chondral bone that has a median position, the orbitosphenoid. The latter extends anteriorly and ventrally, producing an incomplete interorbital septum. The lateral eth- moid is well developed, but its preservation does not allow a proper description. A section of the parasphenoid is visible throughout the large orbit. It has a well-developed ascendent process suturing with the pterosphenoid. Anteriorly, the 
parasphenoid sutures with the well-developed posterior process of vomer (Fig. 3b); however, the suture between both bones is unclear in other specimens (Fig. $4 \mathrm{a}-\mathrm{b}$ ). There are numerous, minuscule teeth scattered below the parasphenoid, vomer, and entopterygoid (Figs. $3 \mathrm{~b}$ and $4 \mathrm{~b}$ ). Because of the angle at which some of those teeth are preserved in JME ETT 132a, it is possible to assume that not only the entopterygoid carried teeth but also the vomer and parasphenoid. This assumption should be tested when more specimens become available. It is unclear whether a basipterygoid process was present or not.

The supraorbital canal is a simple canal with a few tubules. The short parietal branch (Fig. 3b) is rudimentary and does not extend posteriorly into the postparietal bone. The supraorbital canal does not produce a lateral tubule near the autosphenotic; thus, a connection between supra- and infraorbital canals is absent. Due to condition of preservation, the otic canal was not observed in the studied material.

Orbit and circumorbital series: The fish has a large orbit (Figs. 2a-c and 3a-b), so that the postorbital distance between the margin of the orbit and the preopercle is very narrow. This space is partially covered by the narrow and small infraorbitals 4 and 5, which do not reach the preopercle posteriorly, so that the dorsal part of the hyomandibula is exposed laterally (Figs. 3b, 4a-b, and 5).

The series of circumorbital bones apparently encloses the large orbit completely, although a dermosphenotic is not preserved in the studied specimens. However, given the space between the most posterodorsal infraorbital and the autosphenotic, it is assumed that the bone was small. The series includes a supraorbital, antorbital, and five (occasionally six?) infraorbitals (Figs. 3b, 4a-b, and 5). Specimen JME ETT 148 seems to have six infraorbitals (Fig. 5); however, and by comparison with other specimens, I prefer to interpret this 6th bone as result of a fracture of infraorbital 5, and not as a dermosphenotic, because the infraorbital canal does not turn posteriorly to join the otic canal. There are two large sclerotic bones occupying anterior and posterior positions.

The supraorbital bone (Fig. 4a-b) is large, well ossified, and expanded anteriorly. Only its anteriormost portion is preserved in the holotype (Fig. 3b). Because of its size and it being displaced in all specimens, it is interpreted here as a bone that covers most of the dorsal margin of the orbit.

The antorbital (Fig. 3b) is a slightly elongate, triangular bone that is comparatively larger than antorbitals present in other Jurassic teleosts. An antorbital branch of the infraorbital canal has not been observed.

Infraorbital 1 (Figs. 3b, 4a, and 5) is an elongate, narrow bone that is slightly broader at its anterior margin than posteriorly. Infraorbital 2 (Figs. 3b, 4a, and 5) is long and narrow, but becomes broader at its posteroventral corner, joining infraorbital 3. The bone is so long that it is the main element forming the ventral margin of the orbit. Infraorbital 3 (Figs. 3b, 4a-b, and 5) is a small, slightly square bone at the posteroventral corner of the orbit. Its posterior margin just reaches the anterior margin of the preopercle or both bones are separated by a short distance. Due to the small size of infraorbital 3, the quadrate is partially exposed laterally. Infraorbitals 4 and 5 form the posterodorsal margin of the orbit.

The infraorbital canal (Figs. 3b, 4a-b, and 5) is enclosed by thin bone and is of simple type. The main canal is relatively broad, with a few branching sensory tubules. At least three tubules are counted in infraorbital 1 . They open close to the ventral margin of the bone. No sensory tubules branch off in infraorbitals 2, 4, and 5. Infraorbital 3 has only one or two sensory tubules that end at the middle region of the bone. Upper jaw: Premaxilla, maxilla, and two supramaxillae form the upper jaw. The premaxilla (Figs. $3 \mathrm{~b}$ and $4 \mathrm{a}-\mathrm{b}$ ) is a slightly triangular bone, with a short, broad ascendent process and an elongate oral margin, which is as long as the elongate anterior articulatory region of the maxilla. The oral margin bears small, conical teeth. It is unknown how many rows of teeth were present.

The maxilla (Figs. $3 \mathrm{~b}$ and $4 \mathrm{a}-\mathrm{b}$ ) is elongate, partially covering the lateral aspect of the quadrate and extending close to the posterior margin of the orbit. Its articulatory anterior region is about a third of the maxillary length. The ventral margin is slightly convex, as is its posterior margin. A row of small, conical teeth that increase in size posteriorly is present. The teeth are comparatively larger in younger states than in older (larger) specimens. The posterolateral side of the maxilla - which is well preserved in the holotype - presents small, rounded tubercles (Fig. 3b), an uncommon feature in Late Jurassic teleosts, which lack ornamentation.

Two supramaxillae (Figs. 3b, 4a-b, and 5) lie on the dorsal margin of the maxilla. Both bones together occupy the whole length of the maxillary blade. Supramaxilla 2 has a broad, expanded body and a narrow, long anterodorsal process that almost covers the whole dorsal margin of supramaxilla 1 , which is slightly ovoid.

Lower jaw: The jaw (Figs. $3 \mathrm{~b}$ and $4 \mathrm{a}-\mathrm{b}$ ) is moderately long, with its articulatory region for the quadrate placed at the level of the posterior half of the orbit. The jaw is formed laterally by two bones, the dentary and the angular. The suture between both bones is not visible because of preservation, although discontinuous sections are observed in some specimens. From a narrow mandibular symphysis, the dentary expands posteriorly, producing together with the angular a massive and high coronoid process. A "leptolepid" notch has not been observed, because the maxilla covers the region where the notch would be placed. A retroarticular has not been observed in any specimen, so that it is assumed that the angular, articular, and retroarticular are fused in the medial side of the jaw. The postarticular process is elongate and well ossified. A narrow section of a chondral bone is medial to the ventral margin of the angular in specimens JME ETT 60 and is interpreted here as part of a branchial arch.

A surangular is not present at the posterodorsal corner of the jaw. Coronoid bones are not present either. 

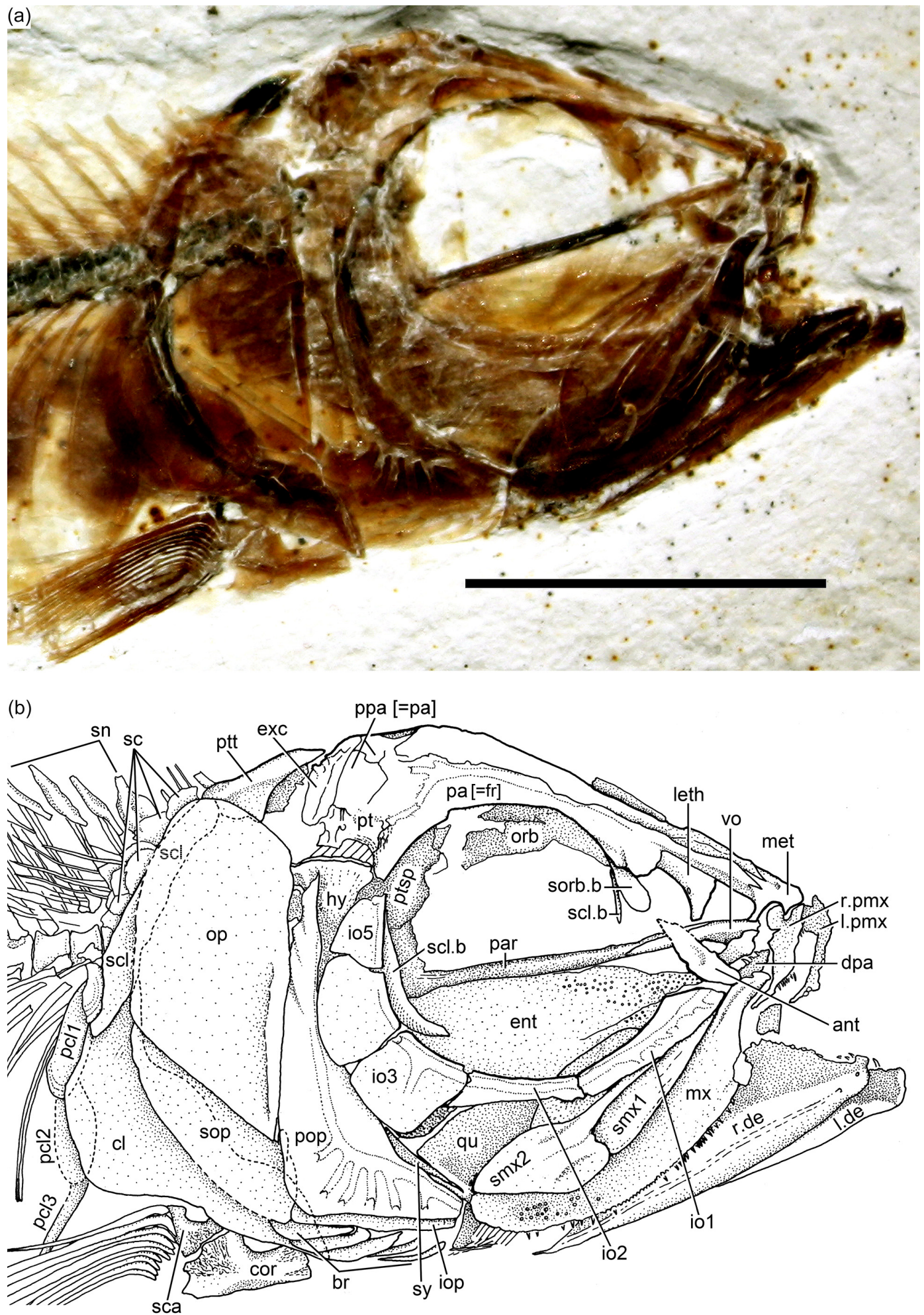

Figure 3. Ebertichthys ettlingensis n. gen. et n. sp. in lateral view (holotype JME ETT 108). (a) Photograph of cranium and anterior part of body. Photograph courtesy of M. Ebert. Scale equals $1 \mathrm{~cm}$. (b) Drawing of cranium and anterior part of body. Abbreviations: ant, antorbital; br, branchiostegal rays; cl, cleithrum; cor, coracoid; dpa, dermopalatine; ent, entopterygoid; exc, extrascapula; hy, hyomandibula; io1-5, infraorbitals 1-5; iop, interopercle; 1.de, left dentary; leth, lateral ethmoid; 1.pmx, left premaxilla; met, mesethmoid; mx, maxilla; op, opercle; orb, orbitosphenoid; pa[= fr], parietal [= frontal bone of traditional terminology]; par, parasphenoid; pcl1-3, postcleithra 1-3; pop, preopercle; $\mathrm{ppa}[=\mathrm{pa}]$, postparietal [= parietal bone of traditional terminology]; pt, pterotic; ptsp, pterosphenoid; ptt, posttemporal; qu, quadrate; sc, scales; sca, scapula; scl, supracleithrum; scl.b, broken sclerotic bone; smx1-2, supramaxillae 1-2; sn, supraneurals; sorb.b, broken supraorbital bone; sop, subopercle; sy, symplectic; r.de, right dentary; r.pmx, right premaxilla; vo, vomer. 
(a)

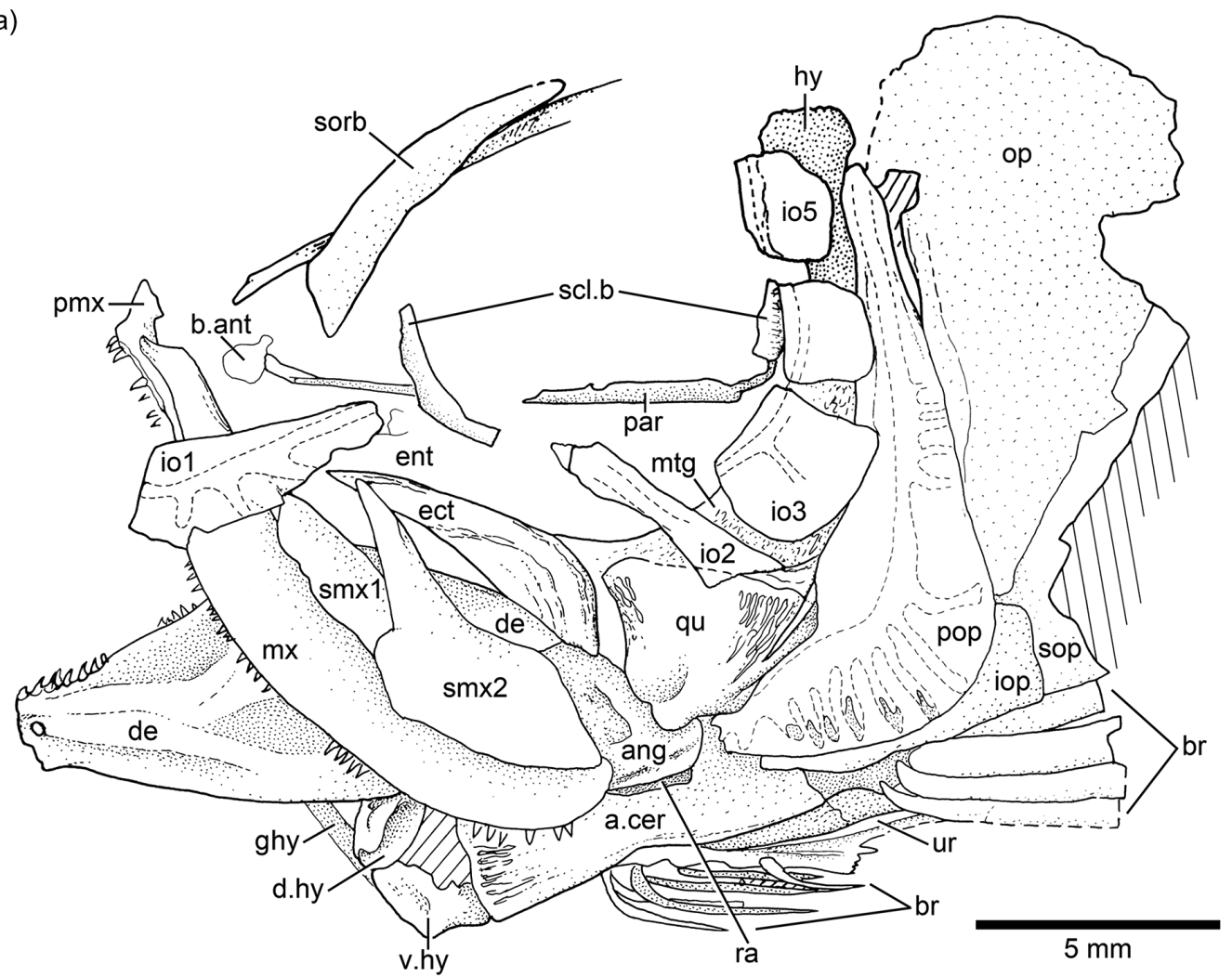

(b)

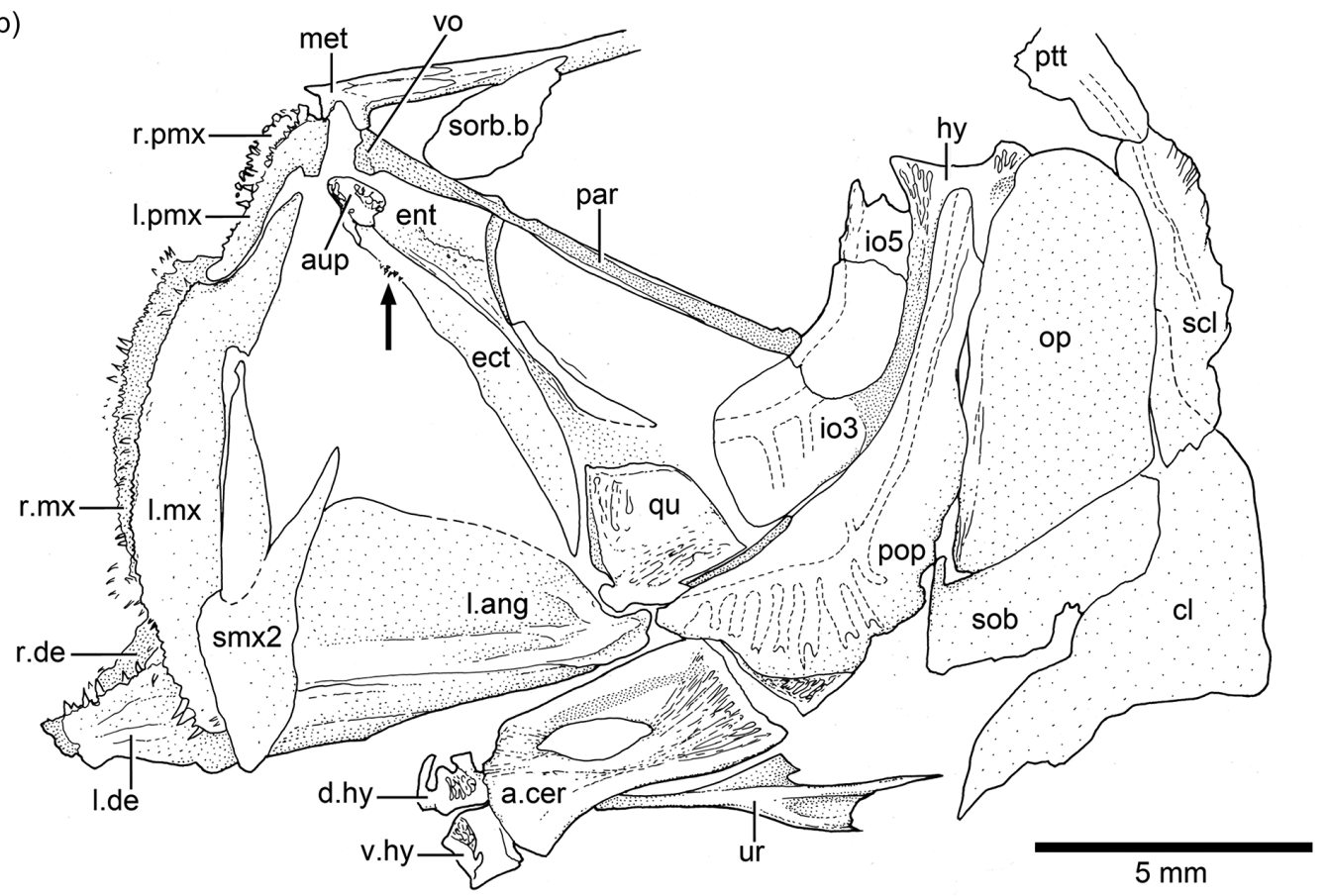

Figure 4. Ebertichthys ettlingensis n. gen. et n. sp. Crania in lateral views illustrating specific morphological features. (a) JME ETT 60. (b) JME ETT 24. Arrow points to a small toothed patch. Abbreviations: ang, angular; aup, autopalatine; b.ant, broken antorbital; a.cer, anterior ceratohyal; br, branchiostegal rays; cl, cleithrum; de, dentary; ect, ectopterygoid; ent, entopterygoid; ghy, glossohyal; d.hy, dorsal hypohyal; iop, interopercle; hy, hyomandibula; io1-5, infraorbitals 1-5; l.ang, left angular; 1.de, left dentary; 1.pmx, left premaxilla; met, mesethmoid; mtg, metapterygoid; mx, maxilla; op, opercle; par, parasphenoid; pmx, premaxilla; pop, preopercle; ptt, posttemporal; qu, quadrate; ra, remnant of a branchial arch; r.de, right dentary; r.pmx, right premaxilla; scl, supracleithrum; scl.b, broken sclerotic bones; smx1-2, supramaxillae 1-2; sorb, supraorbital; sop, subopercle; ur, urohyal; v.hy, ventral hypohyal; vo, vomer. 


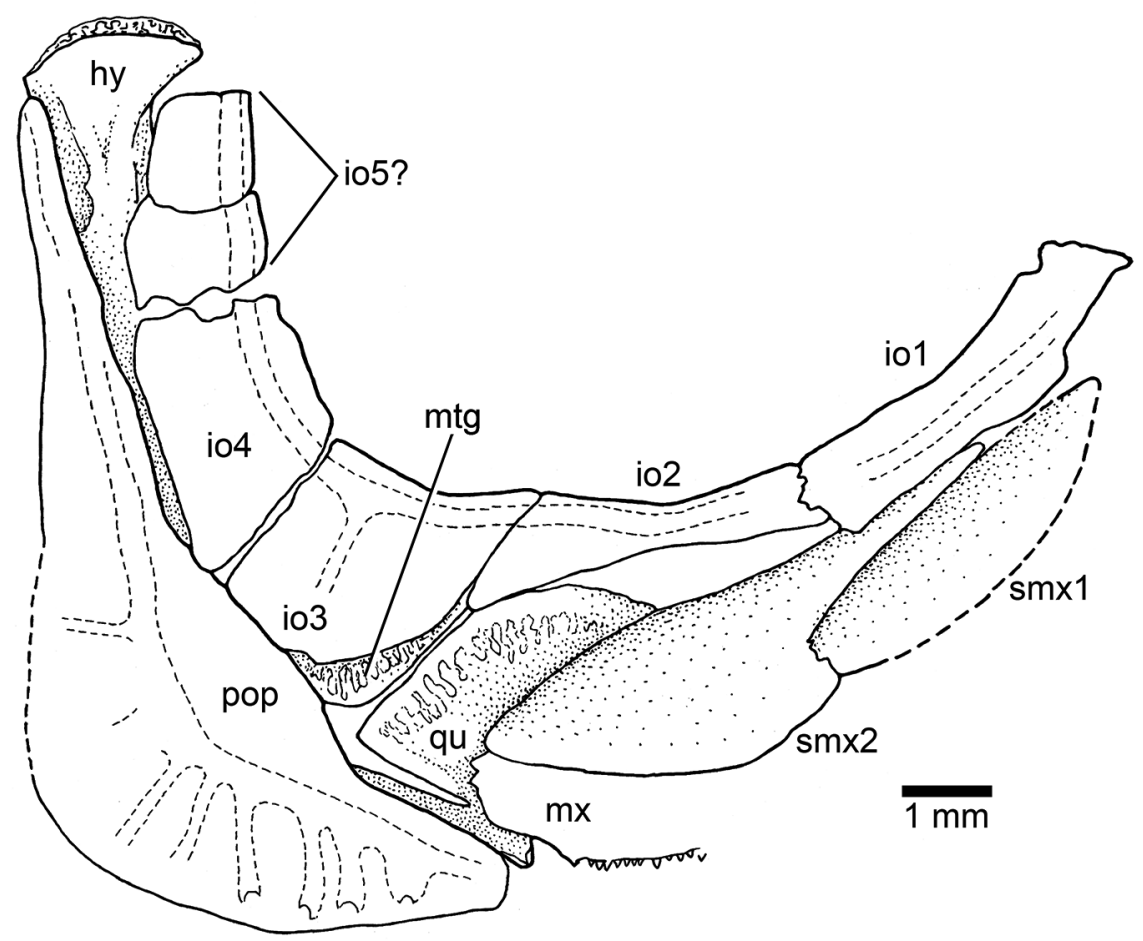

Figure 5. Ebertichthys ettlingensis n. gen. et n. sp. Infraorbital bones, preopercle, suspensorium, and part of upper jaw (JME ETT 148). Abbreviations: hy, hyomandibula; io1-4, infraorbitals 1-4; io5?, broken infraorbital 5?; mtg, metapterygoid; mx, maxilla; pop, preopercle; qu, quadrate; smx1-2, supramaxillae 1-2.

The mandibular canal is positioned near the ventral margin of the jaw. Pores have not been observed in the posteroventral region of the dentary and angular, so that it is assumed here that the mandibular canal exits medially.

Palatoquadrate, suspensorium, hyoid arch, glossohyal, and urohyal: Most of these bones are partially hidden by other bones, so that a complete description is restricted to a few elements. A small, somewhat square autopalatine (Fig. 4b) is placed lateral to the vomer, and slightly dorsal to a small dermopalatine. The latter bears very small, conical teeth. The autopalatine and quadrate are separated by a thin, elongate entopterygoid (Figs. 3b and $4 b$ ) that is covered medially with tiny conical teeth, at least at the anterior part of the entopterygoid and below the orbit. The ectopterygoid (Fig. 4b) is lateral to the entopterygoid and in front of the quadrate. The bone is elongate, boomerang-like, and has a small patch of tiny, conical teeth close to the palatine region. The quadrate (Figs. 3b, 4b, and 5) is slightly triangular, with its dorsal margin straight or slightly rounded, and a comparatively small, slightly rounded condyle for articulation with the lower jaw. Its posterodorsal margin sutures with the metapterygoid. The length of the posterodorsal process of the quadrate is unknown because the process is covered by the anterior margin of the preopercle. A small portion of the metapterygoid (Figs. 3b, 4a, and 5) can be observed below the small infraorbital 3. Only a portion of the upper region of the hyomandibula (Figs. $3 \mathrm{~b}$ and $4 \mathrm{~b}$ ) and a portion of the ventral region of the symplectic are observed, because those bones are covered laterally by the posterodorsal infraorbitals and the preopercle. The dorsal portion of the hyomandibula (Figs. 3b, 4a-b, and 5) is narrow and apparently has one elongate articular region with the braincase.

The lower part of the hyoid arch has preserved the hypohyals, anterior ceratohyal, and a small portion of the posterior ceratohyal. The posterior ceratohyal is partially observed below the preopercle in specimen JME ETT 24. The dorsal and ventral hypohyals (Fig. 4a-b) are slightly rectangular, and the ventral one is slightly larger than the dorsal one. The anterior ceratohyal (Fig. 4a-b) is rectangular, with an ovoid "beryciform" foramen in its middle region, below the groove for the hyoidean artery. The anterior and posterior borders of the anterior ceratohyal are almost straight with no articular interdigitations.

The glossohyal (Fig. 4a) is a small and elongate narrow bone extending anterodorsally to the dorsal hypohyals. An elongate, triangular urohyal (Fig. 4a-b) is preserved in specimen JME ETT 24 . The bone is narrow anteriorly and expands posteriorly producing three processes, the longest being the middle one.

Opercular and branchiostegal series and gular plate: The preopercle (Figs. 3b, 4a-b, and 5) is triangular-shaped, with its posterior and ventral margins forming an angle of about 
$90^{\circ}$. The bone is not expanded posteroventrally, but it has a characteristically slightly rounded flange just anterior to the curvature of the preopercular canal. Its dorsal arm is long, almost reaching the posterolateral margin of the pterotic, whereas the ventral arm is short. All margins are smooth.

Due to conditions of preservation, the preopercular canal and its tubules (Figs. 3b, 4b, and 5) are incomplete in most specimens, with the exception of JME ETT 60 with sensory tubules preserved in both the ventral and dorsal regions (Fig. 4a). Apparently, the preopercular canal gives off seven or eight tubules in the ventral arm and at least five or six tubules in the dorsal arm. The tubules are very delicate, simple, and narrow, and they open close to the margins of the bone. They are difficult to observe due to the transparency of the bone, and this may explain the differences observed among specimens illustrated herein.

The opercle (Figs. 3b and 4a-b) is large and dorsally is broadly separated from the skull roof bones and the braincase. The dorsal margin is gently rounded, whereas the anterior and posterior margins are almost straight, and the ventral margin is markedly oblique. The surface of the bone is smooth with its anterior margin thickened and heavily ossified.

The subopercle (Figs. $3 \mathrm{~b}$ and $4 \mathrm{a}-\mathrm{b}$ ) is a moderately narrow bone. Its depth is 4 times less than in the opercle. Its ventral margin is gently curved, and its anterodorsal process is short and rounded. The interopercle (Figs. 3b and 4a) is covered by the preopercle (or is not preserved) in most specimens, so that a description cannot be presented. Apparently, the interopercle is as long as the ventral margin of the preopercle as shown by the holotype.

There are 10 incompletely preserved branchiostegal rays (Fig. 4a) in specimen JME ETT 60; six narrow and short branchiostegals articulate with the anterior ceratohyal, and four broader ones articulate with the posterior ceratohyal. Eleven rays are counted in the holotype, the first ones narrow and partially destroyed. Nevertheless, it is possible that the number was much higher than 11. A gular plate has not been observed.

Vertebral column and intermuscular bones: There are 38 or 39 vertebrae, including preural centrum 1; from these, 21 or 22 are abdominal or precaudals, so that the caudal region is shorter than the abdominal one. The first four or five vertebrae are covered laterally by the opercle. All vertebrae are well ossified and with smooth lateral surfaces (Figs. 2a-c, 6a-b, 7, and 8). The centra are almost square, as deep as long, with the exception of the preural centra that are slightly deeper than long and of the ural centra, which are reduced in size. All centra lack pre- and postzygapophyses.

The neural arches of the abdominal vertebrae are autogenous, and the halves of each arch are unfused medially. The neural arches are comparatively narrow and sit on the middle of the dorsal region of each centrum. Each neural arch (Figs. 3b and 6a-b) is slightly expanded proximally, and it has a slightly expanded anterior flange that gives the arch a bilobate aspect. Each epineural process (Fig. 6b) emerges at the posterolateral margin of the arch. Most of the neural spines of the abdominal region are moderately inclined toward the horizontal, and they are moderately long, just reaching the ventral tips of the supraneurals. The spines are shorter than the epineural processes. The parapophyses (Figs. 3b and $6 \mathrm{a}-\mathrm{b})$ are fused to the anterolateral portion of the centrum, near its ventral margin. Each is formed by a thin chondral ossification with a prominent bony edge surrounding a small articulatory cavity placed ventroposteriorly in the parapophysis. The head of each rib articulates with the small articular cavity.

The neural arches of the caudal vertebrae (Figs. 2a-c, 7, and 8) are fused to their centra, with the exception of the first two or three caudal vertebrae (vertebrae 23 and 24) that have autogenous neural arches. All haemal arches are fused to their respective centra. The neural and haemal spines are narrow and end in an acute tip, with the exception of those of the preural centra. The neural and haemal spines are moderately inclined toward the body axis, with slightly greater inclination caudally. The haemal spines (Fig. 7) are short, not extending between the anal pterygiophores, except for the first two. The neural and haemal spines of the midcaudal region are completely ossified (membrane bone), lacking an internal core of cartilage; however, the condition changes in the preural region (chondral bone; see below).

There are 18 or 19 unquestionable pairs of ribs. The first two articulate with centra that are laterally covered by the opercle, and the last pair is positioned lateral to the first anal pterygiophore. All ribs (Figs. 2a-c, 3b, 6a-b, and 7) are slightly curved, but the curvature is more evident in the rostral direction. The ribs are well ossified and narrow along their length, but slightly expanded at their proximal, small, articulatory heads. Ventrally, they do not reach the margin of the body. There is an unclear pattern between the last centrum bearing a pair of ribs (Fig. 7), which is placed anterolaterally to the first anal pterygiophore, and the first centrum with a complete haemal arch and spine that is positioned above the third anal pterygiophore (Figs. 7 and 8). Between those centra, there are three vertebrae with ventrolateral structures that resemble parapophyses more than haemal arches. Each is associated to an elongate, median structure that is bifid at its proximal head and ends distally in two elongate processes extending between the anal pterygiophores. If these are modified ribs, then they occupy a median position, but if these are modified haemal spines, then they are unique, because they are bifid distally. I have not observed similar structures in other fossil teleosts.

A complete series of about 16 supraneural bones (Figs. 2ac, $3 \mathrm{~b}$, and $6 \mathrm{a}$ ) extends between the posterior part of the cranium and the processes of the first dorsal pterygiophore. The anteriormost supraneurals are larger and expanded anteroposteriorly than the following ones, which become narrower and smaller posteriorly. The supraneurals are slightly sigmoid or curved. They are placed above or just between the 
(a)

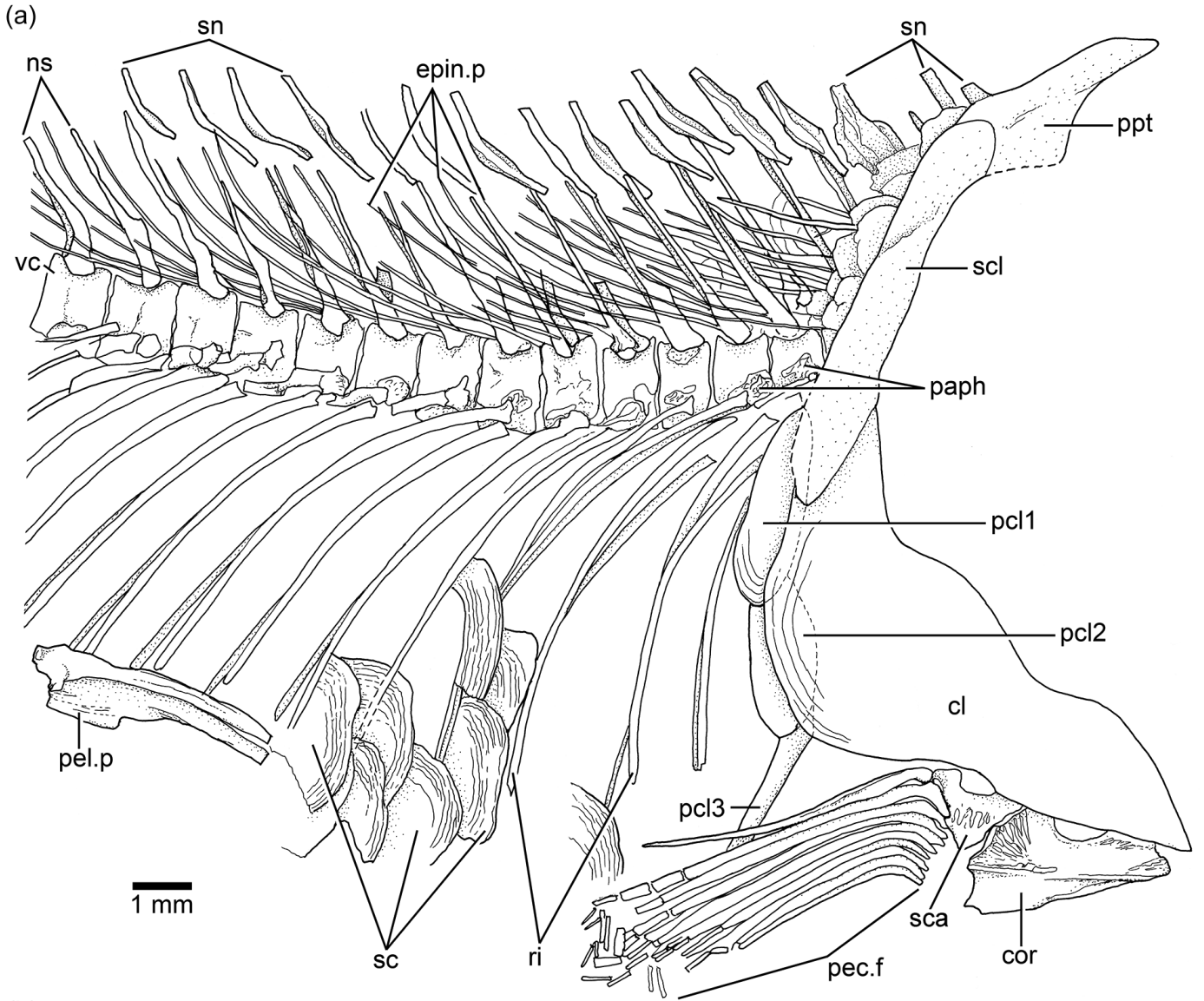

(b)
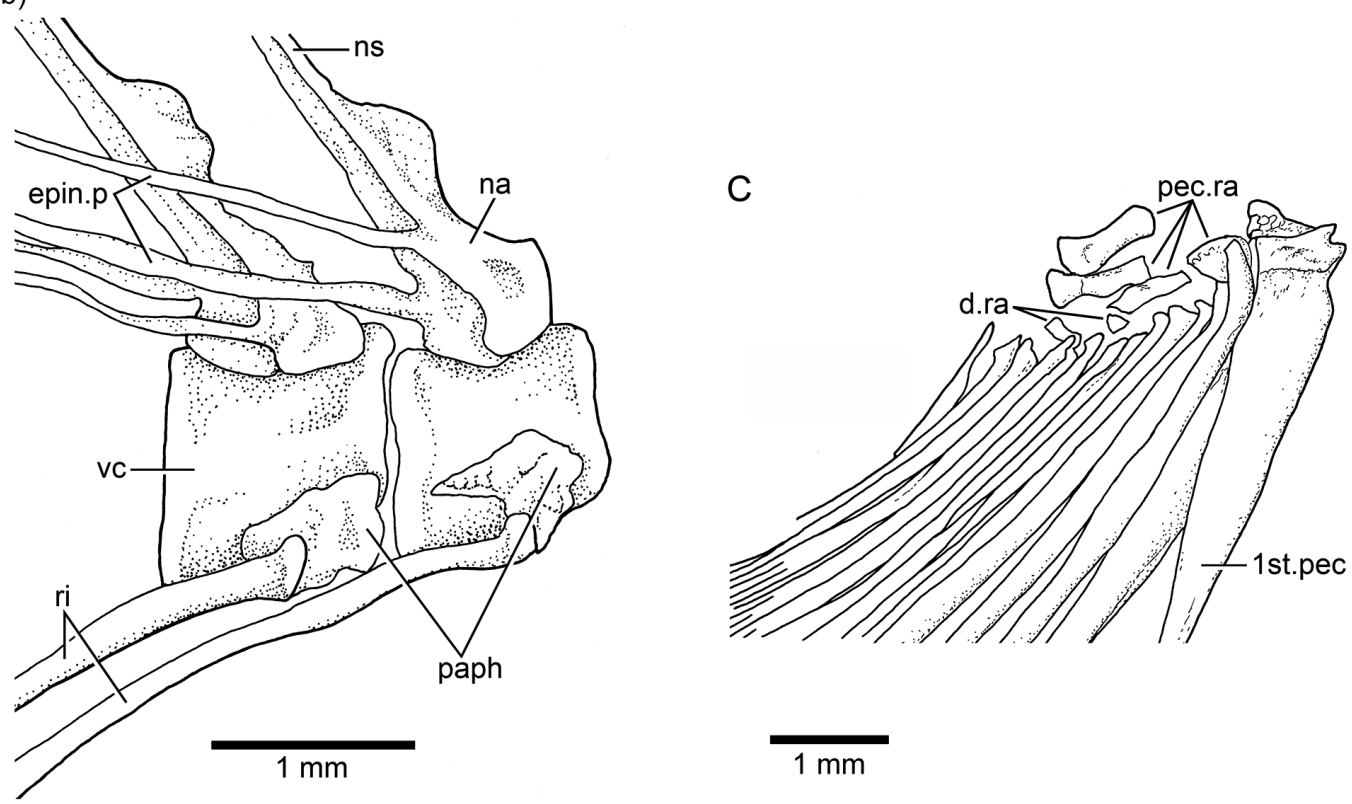

$1 \mathrm{~mm}$

Figure 6. Ebertichthys ettlingensis n. gen. et n. sp. Details of certain abdominal vertebrae and pectoral fin. (a) Anterior abdominal region and pectoral girdle and fin (holotype JME ETT 108). (b) Enlargement of a few abdominal vertebrae illustrating details of the epineural processes (holotype JME ETT 108). (c) Details of pectoral fin and radials (JME ETT 132a). Abbreviations: cl, cleithrum; cor, coracoid; d.ra, distal radials; epin.p, epineural process; na, neural arch; ns, neural spine; paph, parapophyses; pcl1-3, postcleithrum 1-3; pec.f, pectoral fin; pec.ra, proximal radials supporting pectoral rays; pel.p, pelvic plate; ptt, posttemporal; ri, ribs; sc, anterior field of cycloid scales; sca, scapula; scl, supracleithrum; sn, supraneurals; vc, abdominal vertebral centra; 1st. pec, first pectoral ray. 


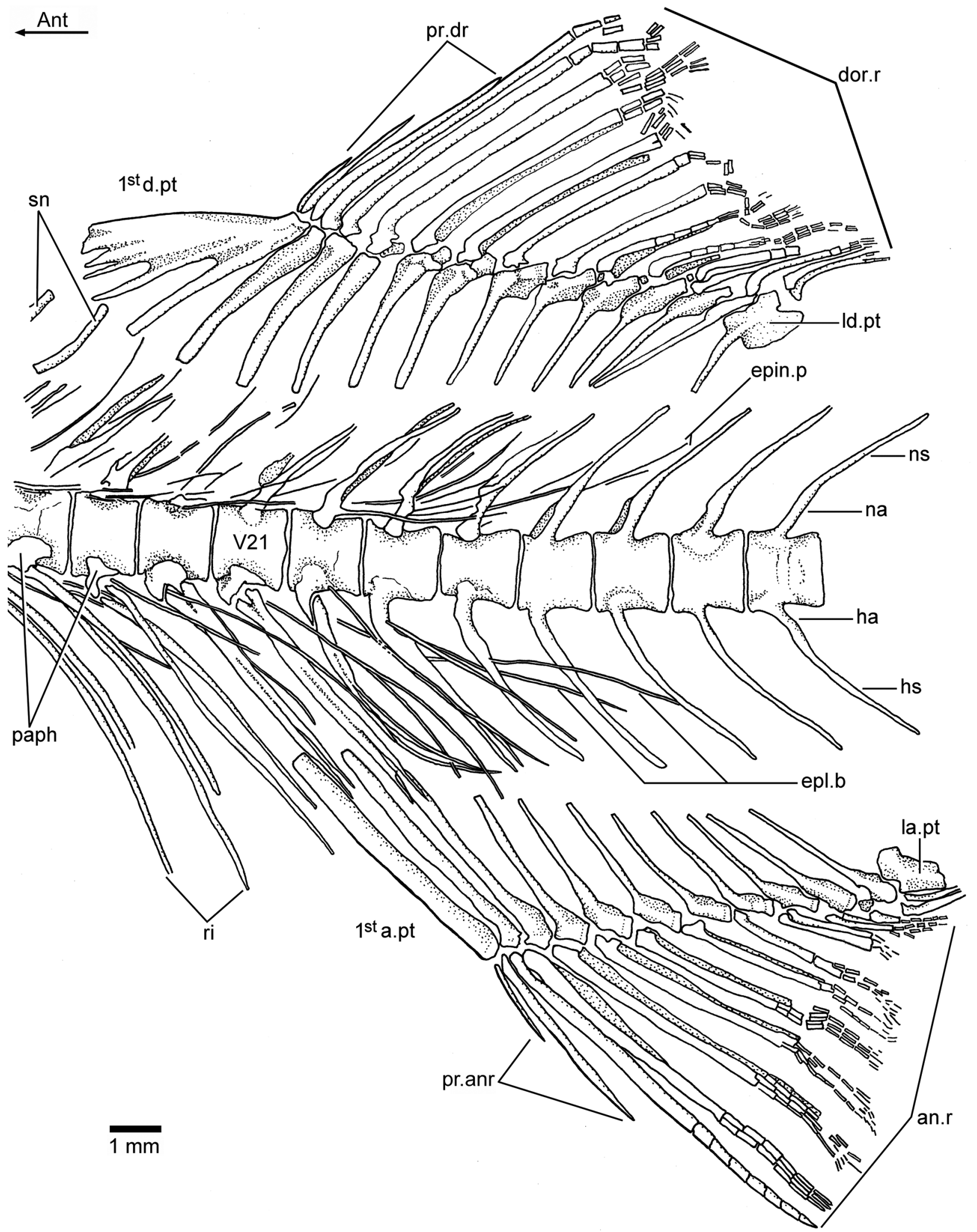

Figure 7. Ebertichthys ettlingensis n. gen. et n. sp. Dorsal and anal fins and their relationships to the vertebral column (JME ETT 132a). Abbreviations: Ant, anterior; an.r, principal anal rays; epl.b, epipleural bones; dor.r, dorsal principal rays; epin.p, epineural processes; ha, haemal arch; hs, haemal spine; la.pt, last anal pterygiophore; ld.pt, last dorsal pterygiophore; na, neural arch; ns, neural spine; paph, parapophyses; pr.anr, anal procurrent rays; pr.dr, dorsal procurrent rays; ri, ribs; sn, supraneural bones; V21, vertebra 21; 1st a.pt, first anal pterygiophore; 1st d.pt, first dorsal pterygiophore. 


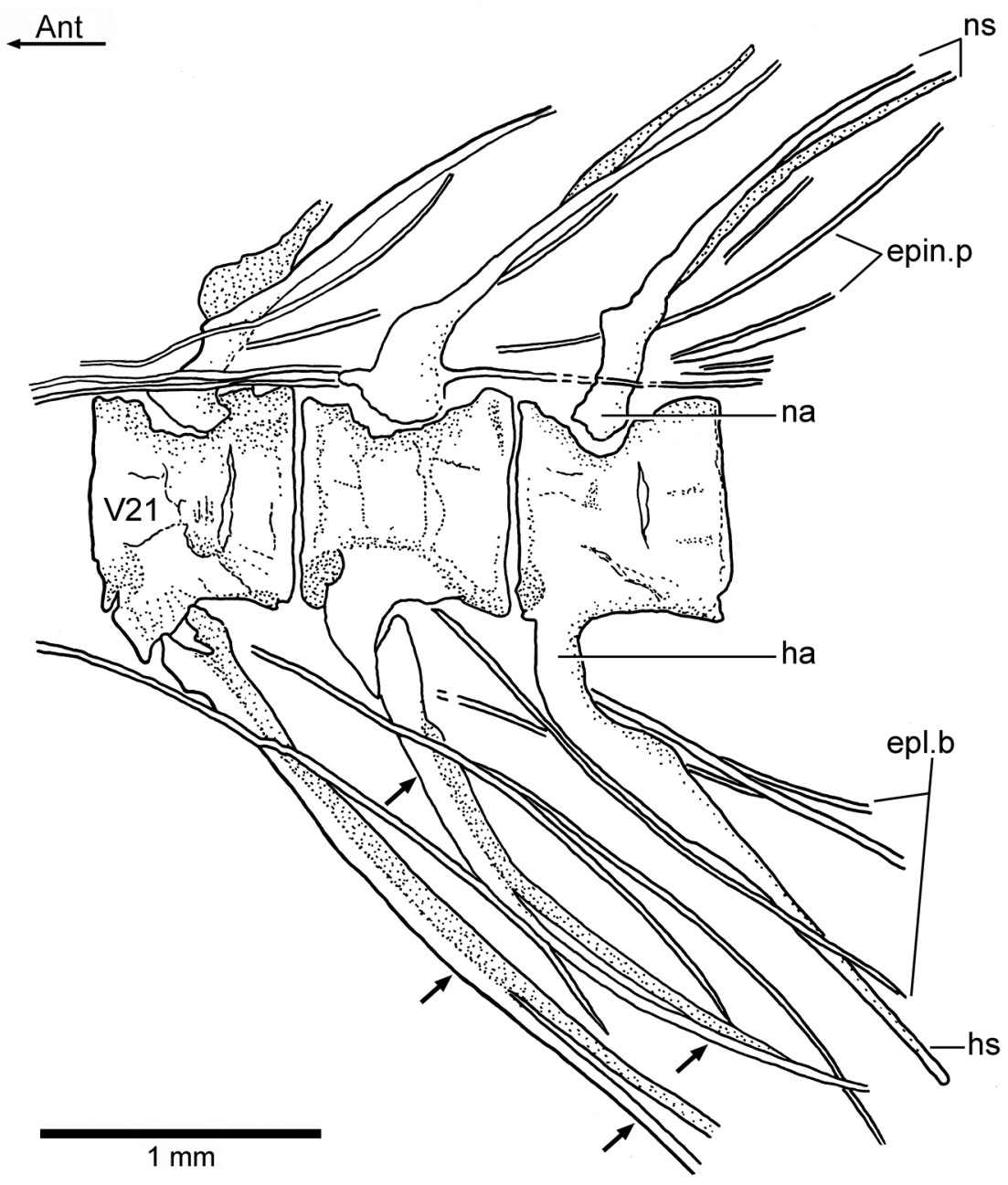

Figure 8. Ebertichthys ettlingensis n. gen. et n. sp. Detail of vertebrae 21-23 and associated intermuscular bones (JME ETT 132a). Small arrows point to a median bone that is bifid distally. Abbreviations: Ant, anterior; epin.p, epineural processes; epl.b, epipleural bones; ha, haemal arch; hs, haemal spine; na, neural arch; ns, neural spine; V21, vertebra 21.

tips of the neural spines, but do not extend into the space between neighboring spines.

The epineural processes of the neural arches (Figs. 2a-c, $3 b, 6 a-b$, and 7) extend along the abdominal region ending close to the end of the dorsal fin. The last pair may arise from the neural arch of vertebra 22 or 23 . The epineural processes are long, extending laterally along the space occupied by five or more centra. They are thin, heavily ossified, and curve posterodorsally, following the angle of the neural spines, with the exception of the last ones, which lie closer to the dorsal margin of the centra than to the tips of the neural spines.

A short series of epipleural bones (Figs. 7 and 8) lies laterally to vertebrae 18 to 26 , in the hypaxial musculature. The epipleurals are very thin, heavily ossified, and extend ventrocaudally to the ventrolateral surface of the last ribs, haemal arches and spines. They can be as long as the epineural processes.
Ontogenetic development of vertebral centra: Each adult abdominal centrum of Ebertichthys ettlingensis is formed by a chordacentrum surrounding and constricting the notochord and an autocentrum around the chordacentrum. In contrast, each adult caudal centrum is formed by the chordacentrum, the autocentrum, and the dorsal and ventral arcocentra that are fused to the autocentrum producing a compact vertebra. In young specimens of Ebertichthys ettlingensis, the caudal centra are unusual, because they present a pseudodiplospondyly. Each centrum presents two small chordacentra or one large chordacentrum. The two hemicentra are separated vertically, and early in ontogeny they fuse into a single chordacentrum. In contrast, the only centrum that forms a chordacentrum in certain vertebrae presents a vertical separation that is lost early in ontogeny, so that only one centrum is observed (Fig. 9a and b). This pseudo-diplospondyly is still observed occasionally in some autocentra showing a verti- 


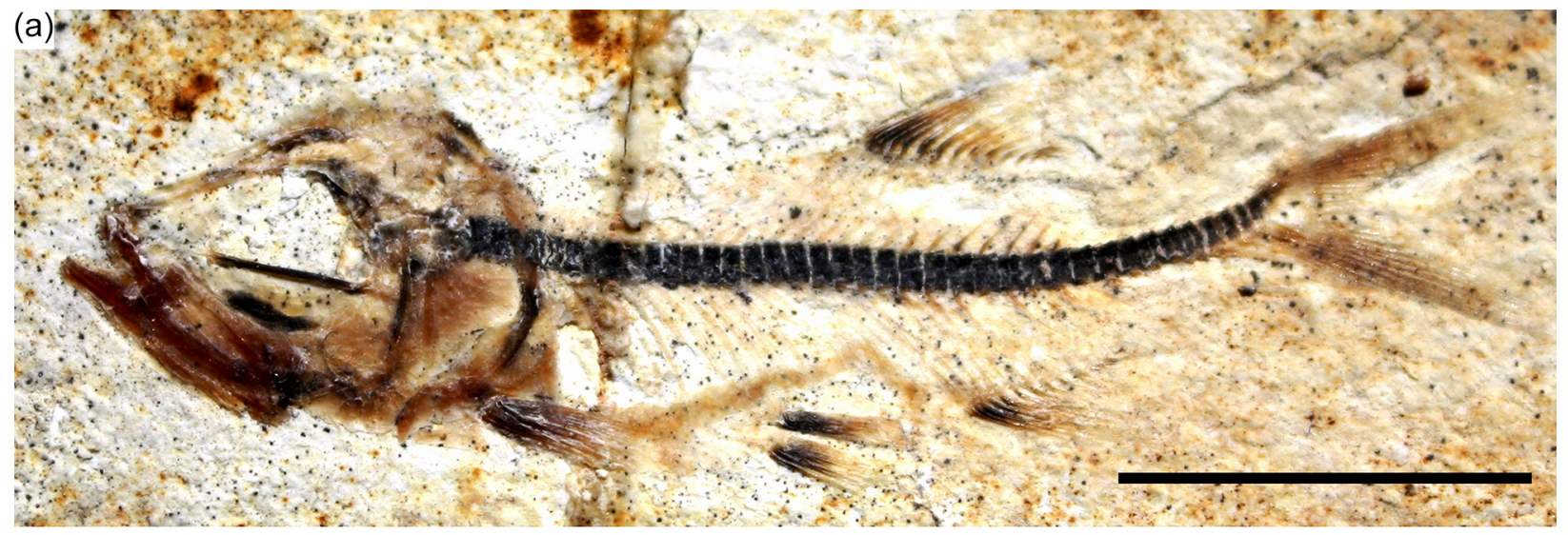

(b)

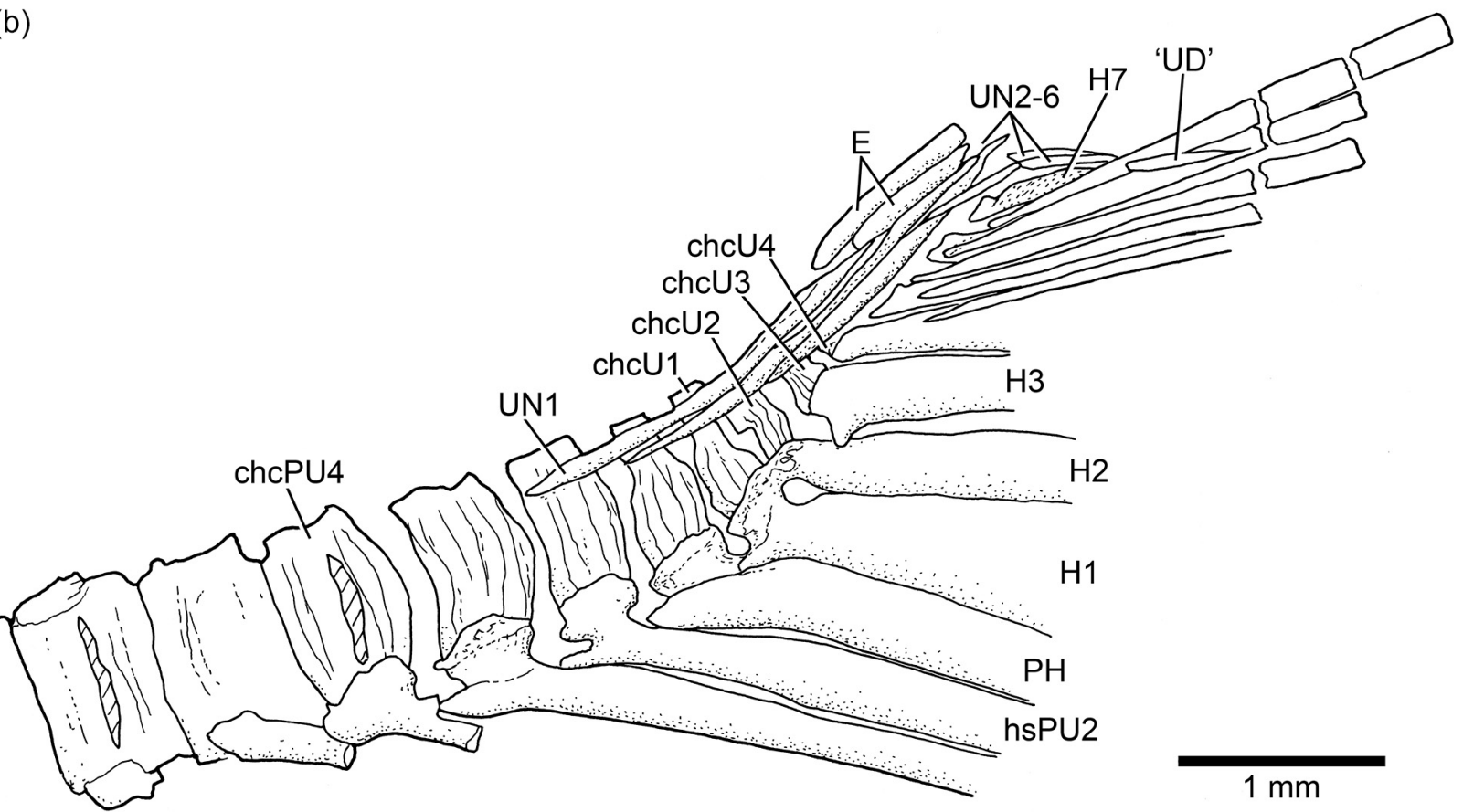

Figure 9. Ebertichthys ettlingensis n. gen. et n. sp. (a) Photograph of young specimen (JME ETT 61) in lateral view. Photograph courtesy of $\mathrm{H}$. Tischlinger, Scale equals $1 \mathrm{~cm}$. (b) Detail of last caudal vertebrae illustrating pseudo-diplospondyly and caudal endoskeleton incompletely preserved. Abbreviations: chcPU4, chordacentrum of preural centrum 4; chcU1-3, chordacentra of ural centra 1-3; E, epurals (the first one is missing); H1-7, hypurals 1-7; hsPU2, haemal spine of preural centrum 2; PH, parhypural; 'UD', "urodermal”; UN1-6, uroneurals 1-6.

cal "fracture" separating incompletely anterior and posterior regions in a centrum.

A series of caudal chordacentra (Fig. 8b) is illustrated in a specimen of $34.7 \mathrm{~mm}$ standard length of Ebertichthys n. gen. A few centra show an elongate vertical gap on the lateral wall of the chordacentra. Each caudal chordacentrum is proportionally large, but its size reduces strongly caudally. Hypurals 1 to 4 are supported each by a chordacentrum, revealing a polyural condition in early ontogeny. Ural chordacentra 1 and 2 fuse during ontogeny, then are surrounded by the autocentrum producing a compound ural centrum $1+2$ that articulates with hypurals 1 and 2 . Then, the three elements become fused (see below).
Pectoral girdles and fins: The bones of the pectoral girdle and fins (Figs. 3b, 6a and c) are very well preserved in a few specimens, including the holotype, and this permits a detailed description. The posttemporal is a large bone with an almost rectangular body and a long and broad dorsal process articulating with the cranium. The ventral arm is apparently short because it was not observed in any of the specimens due to the position of the preserved bone. The main lateral line apparently is positioned along the main body of the posttemporal and exits at its posteroventral margin. No sensory tubules have been observed, only the main canal.

The supracleithrum (Figs. 3b, 4b, and 6a) is a narrow, long bone extending from just at the level of the dorsal margin of 


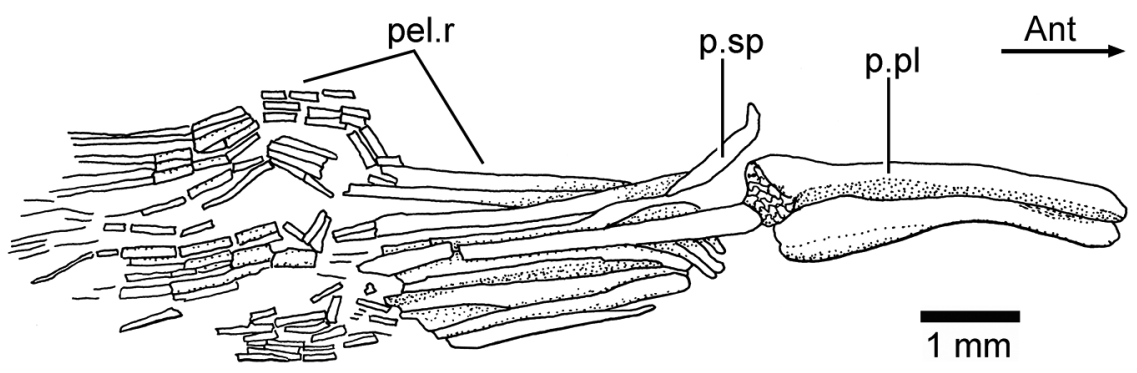

Figure 10. Ebertichthys ettlingensis n. gen. et n. sp. Pelvic plate and pelvic fin (JME ETT 108). Abbreviations: Ant, anterior; pel.r, pelvic rays; p.pl, pelvic plate or basipterygium; p.sp, pelvic splint.

the opercle to the level of the subopercle, below the suture between the opercle and subopercle and far below the level of the vertebral column. Its posterior margin is slightly crenulated in JME ETT 24. The lateral line is placed in the upper middle of the bone and exits about the level of the vertebral column.

The cleithrum (Figs. 3b and 6a) is a compact, heavily ossified bone with a short dorsal limb, a slightly expanded posteroventral corner, and a narrower, short ventral limb inclined anteroventrally. The anteromedial flange of the cleithrum is expanded, almost rounded, giving the bone a characteristic shape, unique among Jurassic teleosts.

Three postcleithra (Figs. $3 \mathrm{~b}$ and $6 \mathrm{a}$ ) are present. The first one is placed at the junction between the supracleithrum and cleithrum, the second one is partially covered by the posteroventral expansion of the cleithrum, and the third one is ventral to postcleithrum 2. Postcleithra 1 and 2 are ovoid shaped, whereas postcleithrum 3 is styliform.

The scapula and coracoid (Fig. 3b) are preserved in the holotype, but not the proximal and distal radials. The coracoid is slightly L-shaped and ends anteriorly in a moderately broad and straight symphysis. Four proximal radials and a few distal radials are preserved in JME ETT 132a (Fig. 6c).

The pectoral fin (Figs. 2a-c, 3b, and $6 \mathrm{~b}-\mathrm{c}$ ) has a low position on the flank, near to the ventral margin of the body. The total number of pectoral rays is unknown, but specimens JME ETT 132a and JME ETT 148 have 15 rays preserved; the first one is spine-like and thicker than all other rays (Fig. 6c), and with scarce segmentation only at its distal end. This ray is fused with the propterygium. All other rays have very long bases and are only distally segmented and branched. The inner rays become progressively shorter. Pelvic girdles and fins: The pelvic girdles (Figs. 2a-c, 6a, and 10) are well preserved in JME ETT 132 . The basipterygium (triangular pelvic plate) presents a thickened lateral margin that expands anteriorly, while the inner region is thinly ossified bone. The posterior part of the basipterygium is thick and retains a large core of cartilage. A posterior process is apparently missing. No proximal radials have been observed. At least a short splint and nine rays are preserved in JME ETT 132. A short splint and disarticulated rays are preserved in the holotype (JME ETT 108a). Similar to the pectoral rays, the pelvic rays have very long bases and are only distally segmented and finely branched.

Dorsal and anal fins: The dorsal fin has three procurrent rays and 12 principal rays. The first two procurrent rays are very thin and short; the third one is almost the half of the size of the first principal dorsal ray, which is only segmented and is the largest of the series of rays. All principal rays have long bases and are finely segmented and branched distally. The first dorsal pterygiophore (Figs. 7, 9a, and 11a) expands anteroventrally and has one to three processes that are preceded by a flat, almost rectangular bony flange that gives a characteristic shape to the first pterygiophore. This element supports the procurrent rays, whereas the second pterygiophore supports the first principal dorsal ray. Pterygiophores $2-4$ are of similar length, and they do not project ventrally between the neural spines. Pterygiophores 5-12 decrease slightly in size and thickness posteriorly, and the last pterygiophore is markedly expanded, with a moderately long and narrow base. As usual in teleosts, the last pterygiophore bears two small rays, but these rays articulate in different positions with the pterygiophore (Fig. 11b). The basal portion of the pterygiophores, except the first and last ones, have a lanceolate aspect, with thin, small anterior and posterior bony flanges. They are apparently fused with the middle portion or middle radial, whereas the distal portion or distal radial is partially ossified in some of the last pterygiophores (Fig. 7).

The anal fin has, commonly, two or three procurrent and 11 principal anal rays that are supported by 11 pterygiophores. The procurrent rays (Fig. 7) are comparatively much shorter than the first principal, which is only segmented. All principal rays have long bases and are distally segmented and finely branched. The first anal pterygiophore is a long, broad, and flat rectangular bone that may support only the procurrent rays or the procurrents and part of base of the first principal ray. The next two pterygiophores are slightly narrower and shorter than the first one, and the remaining pterygiophores are much shorter and do not reach the distal tips of the haemal spines. They are thinner than the first two pterygiophores, and because of the shape of their bases, they are interpreted as formed by fusion with the proximal and mid- 
(a)

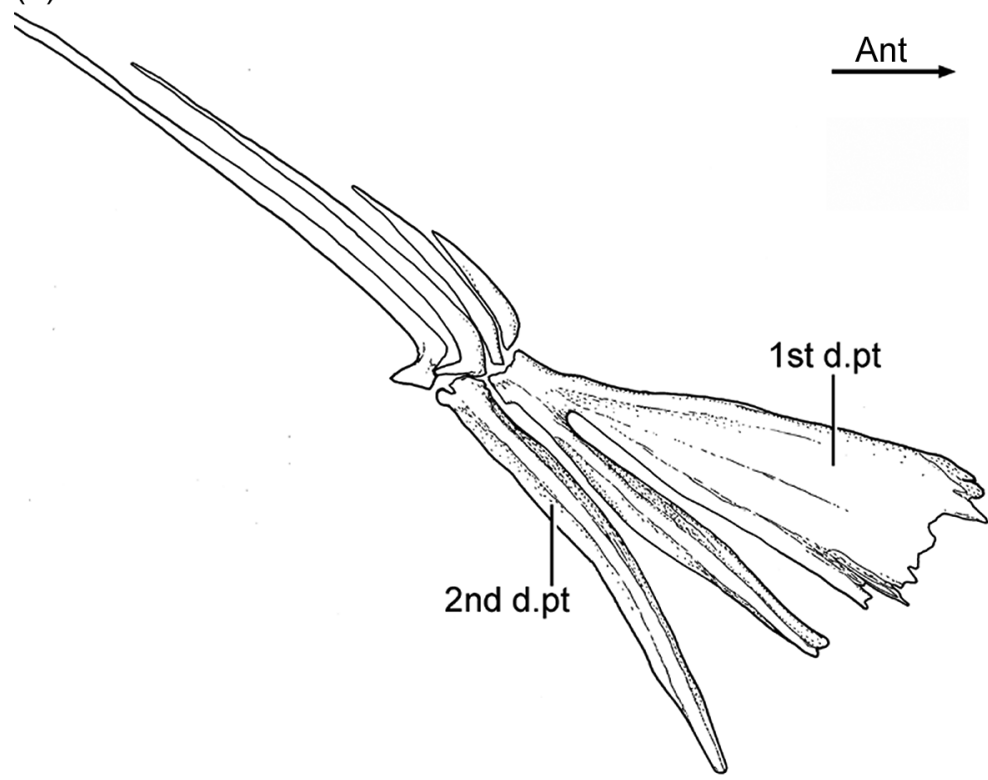

(b)

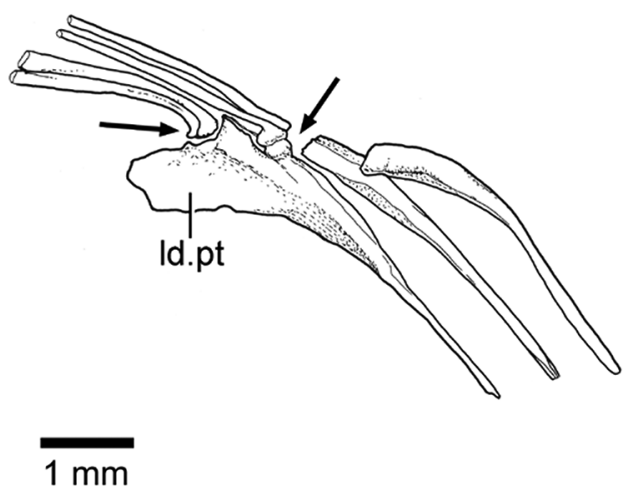

Figure 11. Ebertichthys ettlingensis n. gen. et n. sp. (JME ETT 64a). (a) Details of first two dorsal pterygiophores and first dorsal-fin rays. (b) Detail of last dorsal pterygiophores. Arrows point to the two articular areas for fin rays. Abbreviations: Ant, anterior; 1st d.pt, first dorsal pterygiophore; 2nd d.pt, second dorsal pterygiophore; ld.pt, last dorsal pterygiophore.

dle radials. The distal radials are mostly lost - probably because they were cartilaginous. The last anal pterygiophore is broadly expanded distally and bears two minuscule rays in comparison to the first principal rays.

Caudal fin and endoskeleton: The caudal fin and endoskeleton are preserved in several specimens, so that a detailed description can be presented and intraspecific variation reported. The caudal fin (Figs. 2a-c, 12, and 13) is deeply forked with very short middle principal rays in comparison to the long, leading marginal rays.

Five preural vertebrae support the caudal rays. All these vertebrae are characterized by their smooth surfaces, and their broad dorsal and ventral arcocentra are fused to their respective centrum in larger specimens. They may retain remnants of cartilage in some vertebrae. The neural spines of preural vertebrae $2-5$ are slightly expanded, and they have a central core of cartilage surrounded by a thin perichondral ossification and slightly developed anterior and posterior bony flanges. In the vertebrae that are completely preserved, it is possible to observe the anterior elongate processes at the base of neural spines 1 to 4 . Neural spines 2 to 5 are long, whereas the neural spine of preural centrum 1 is shorter than the preceding ones. The haemal spines of preural centra 1-5 are broader than their respective neural spines. However, the haemal spine of preural vertebra 5 is narrower. The anterior processes located between the base of the haemal arch and spine are slightly rounded. The haemal spines of preural vertebrae are chondral elements; some retain a core of cartilage.
In most specimens the neural and haemal arches of preural vertebra 1 are fused to their centrum, but in specimen JME ETT 108a, the haemal arch is still unfused. A complete neural arch, with its spine, is present on preural centrum 1. This spine is shorter than the preceding spines. The haemal arch and its broad parhypural are fused to the centrum in most specimens (e.g., Fig. 13). A hypurapophysis on the lateral wall of the haemal arch of preural centrum 1 was not observed in any specimen.

Three or four ural centra (of the polyural terminology) are associated with their respective hypurals. The first ural centrum that bears hypurals 1 and 2 results from the fusion of ural centra 1 and 2 (Figs. 9, 12, and 13). Ural centra 3 and 4 are associated with hypurals 3 and 4, respectively. An arch and its spine and an incomplete arch are present above ural centrum $1+2$. A third incomplete arch is present in other specimens (Fig. 13).

The complete number of uroneurals is unclear. Some specimens have four (Fig. 12) or five (Fig. 13) or possibly six (JME ETT 132a) uroneurals preserved. The first uroneural, the longest of the series, extends anteriorly, reaching the lateral surface of preural centrum 2. The second uroneural reaches the lateral surface of preural centrum 1 , and the third uroneural reaches the lateral surface of ural centrum $1+2$. The fourth uroneural is short, reaching anteriorly the base of hypural 6 or 7 . There are other two smaller, elongate elements that I interpret as uroneurals 5 and 6 . The first uroneural may have a small membranous outgrowth. There are three 


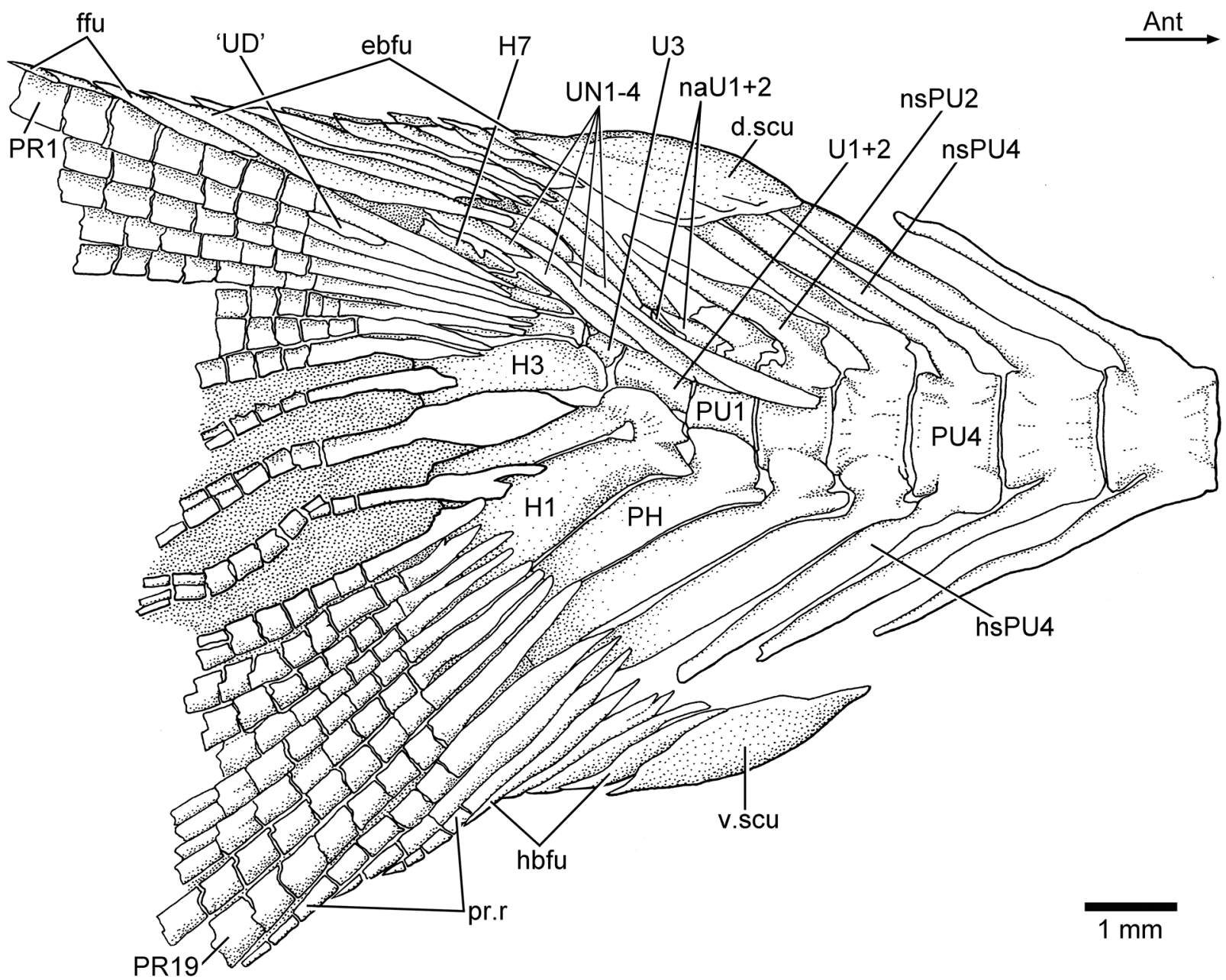

Figure 12. Ebertichthys ettlingensis n. gen. et n. sp. Caudal fin and endoskeleton in lateral view (holotype JME ETT 108). Abbreviations: Ant, anterior; d.scu, dorsal caudal scute; ebfu, epaxial basal fulcra; ffu, fringing fulcra; H1-7, hypurals 1-7; hsPU4, haemal spine of preural centrum 4; nsPU2-4, neural spines of preural centra 2-4; naU1+2, neural arches of ural centrum $1+2$; PH, parhypural; prp, procurrent rays; PU1, 4, preural centra 1, 4; U1+2, 3, ural centrum $1+2$ and 3 (polyural terminology) fused with the bases of hypurals 1 and 2; 'UD', "urodermal"; UN1-4, uroneurals 1-4; PR1-19, principal rays 1-19; v.csu, ventral caudal scute.

elongate epurals occupying the space between the neural spines 1 and 2 and the uroneurals; the first one is the longest.

At least nine hypurals are present. Hypurals 1 and 2 are continuous at their bases, and they fuse to the autocentrum of ural centrum $1+2$ during ontogeny. Hypural 1 is the largest element of the series, and hypural 2 is comparatively narrow. Hypurals 2 and 3 are contiguous to each other, so that the hypural diastema is very narrow or non-existent. Hypural 3 is the broadest among hypurals 3-9, which decrease in size posterodorsally. Hypurals 2 and 3 are partially covered by the expanded bases of the middle principal rays (e.g., 10 and 11).

There are eight or nine epaxial basal fulcra, three fringing fulcra, 19 principal rays, three hypaxial procurrentsegmented rays, and four or five hypaxial basal fulcra (Figs. 12 and 13). One long and slightly fusiform or ovoid dorsal scute and a ventral scute precede the epaxial and hypaxial series of basal fulcra, respectively.

The anterior epaxial basal fulcra in specimen JME ETT 108a are apparently formed by paired elements (Fig. 12); however, the anterior epaxial basal fulcra are unpaired but with two separate, ventral projections in other specimens. The basal fulcra are elongate, leaf-like elements that expand laterally, partially covering the next fulcrum. The three elongate fringing fulcra lie on the dorsal margin of the first principal ray. They can be elongate and of similar size (Fig. 13), or the first one is comparatively longer than the other two (Fig. 12). The bases of the posteriormost basal fulcrum and the first principal caudal ray produce an angle as described for other fishes, mainly teleosts (Arratia, 2008).

Ten principal caudal fin rays are articulated with at least hypurals 3 to 6 . Hypural 6 supports the first principal ray, 


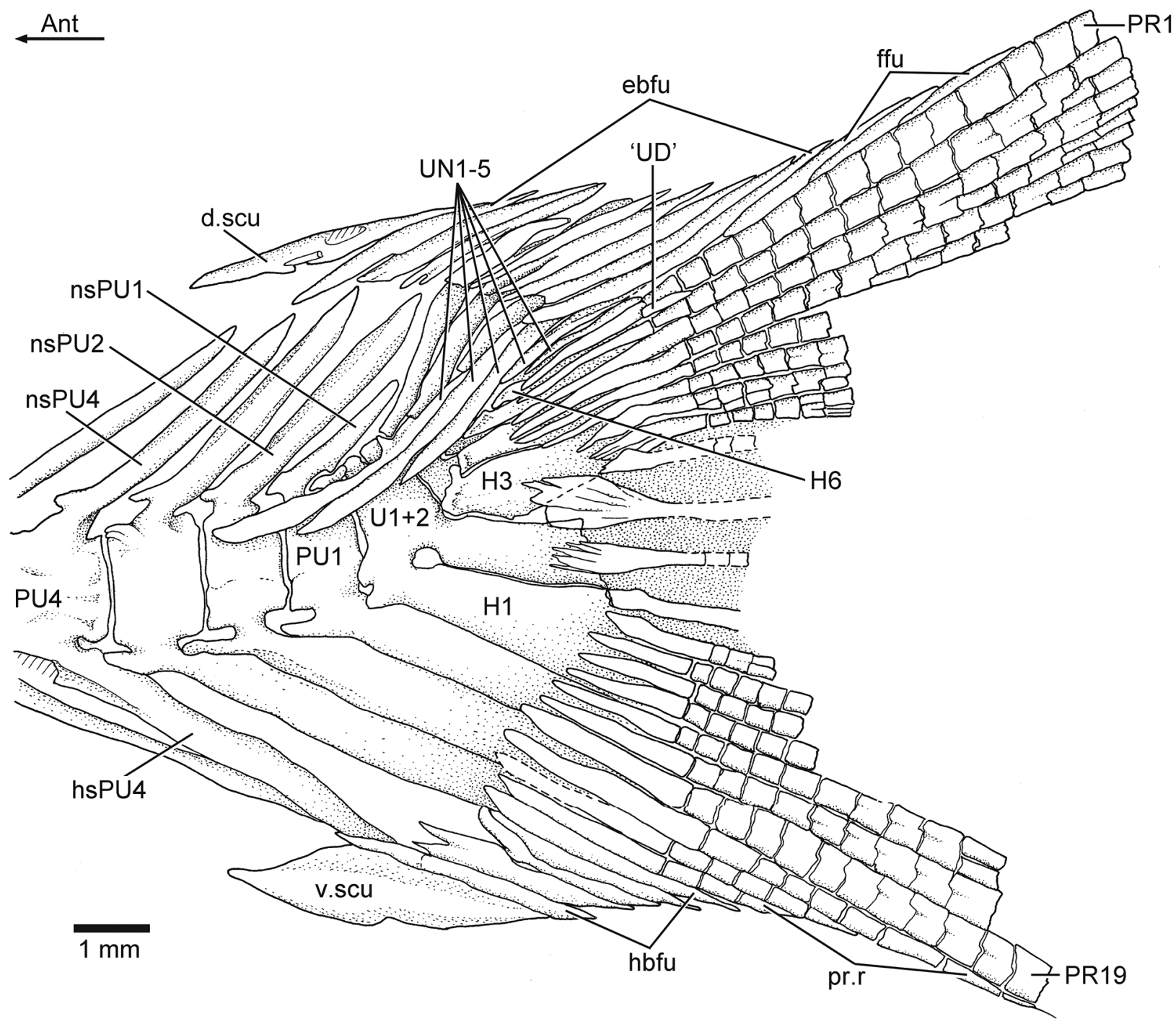

Figure 13. Ebertichthys ettlingensis n. gen. et n. sp. Caudal fin and endoskeleton in lateral view (JME ETT 60). Abbreviations: Ant, anterior; d.scu, dorsal caudal scute; ebfu, epaxial basal fulcra; ffu, fringing fulcra; H1-6, hypurals 1-6; hsPU4, haemal spine of preural centrum 4; mo, membranous outgrowth on anterodorsal margin of first uroneural; nsPU1-4, neural spine of preural centra 1-4; PU1,4, preural centrum 1, 4; $\mathrm{U} 1+2$, ural centrum $1+2$ (polyural terminology) fused with the bases of hypurals 1 and 2; 'UD', "urodermal"; UN1-5, uroneurals 1-5; PR1-19, principal rays 1-19; v.csu, ventral caudal scute.

and the other nine rays are supported by hypurals 3 to 5 . Nine principal rays are supported by hypurals 1 and 2, parhypural, and haemal spine 2 . The articulation between segments of the leading rays is mainly Z- or step-like, whereas the articulation between segments of the inner principal rays is mainly straight. Some of the bases of the middle principal caudal rays are broken, but those that are preserved show that they were expanded (Figs. 12 and 13). Dorsal processes associated with the bases of the middle principal rays of the upper lobe have not been observed in the available material.

One elongate "urodermal" (sensu Arratia and Schultze, 1992) lies between the bases or close to the bases of the first and penultimate principal rays. The "urodermal" is a thin, oval bone (Figs. 12 and 13).

Scales: Thin, large cycloid scales with circuli at their anterior field (Figs. 2a-b, 3a-b, and 6) cover the whole body. No radii are observed. The scales are so large that approximately six rows of scales covered the skin of the flank below the vertebral column and between pectoral and pelvic fins. No remnants of scales are observed on the fin rays. 


\section{Ascalabos Graf zu Münster, 1839b}

Diagnosis (emended from Nybelin, 1974, and Arratia, 1997). (The diagnosis is based on a unique combination of characters. Uniquely derived features among basal teleosts are identified with an asterisk [*].) Small teleosts of about $115 \mathrm{~mm}$ maximum length. Broad, simple cephalic sensory canals with pointed sensory tubules [*]. With low number of vertebrae, 34 to 39 . Caudal centra, mainly midcaudals, with a prominent lateral crest [*]. Seven or eight uroneurals, first four longer than posterior series of three or four. First two uroneurals reaching preural vertebra 3 . Ten or 11 hypurals. Few epaxial segmented procurrent rays posterior to last epaxial basal fulcrum [*]. One rudimentary epaxial ray. Caudal fringing fulcra absent.

Content. Only one species known, Ascalabos voithii.

\section{Ascalabos voithii Graf zu Münster, 1839b}

\section{Figures 14-19}

1839b Ascalabos Voithii - Graf zu Münster, p. 112, pl. XII, fig. 5 .

1843 Leptolepis Voithii - Agassiz, p. 131, 165, 295, pl. LXI, figs. 2-3.

1843 Leptolepis polyspondylus - Agassiz, p. 133, pl. LXI, figs. 7-8.

1843 Leptolepis paucispondylous (nomen nudum) - Agassiz, p. 134.

1848 Leptolepis Voithii - Giebel, p. 143.

1848 Tharsis radiatus - Giebel, p. 146.

1863 Leptolepis Voithii, Wagner, p. 131, 134.

1895 Leptolepis voithii - Woodward, p. 512.

1974 Ascalabos voithi - Nybelin, 173-180, text-figs. 35, 36, pl. XXIX, figs. 1-5, pl. XXX.

1975a Leptolepis (Ascalabos) voithi - Taverne, 233-243, figs. 1-6.

1977 Ascalabos voithii - Patterson and Rosen, 151-152, figs. 52-53.

1991 Ascalabos voithi - Arratia, 268-271, fig. 9.

1997 Ascalabos voithii - Arratia, 31-39, figs. 14-21.

Neotype: The holotype is lost. Nybelin (1974) designated as neotype a specimen identified as Eichstätt I (currently JME SOS 537).

Additional specimens: CM 9491. CMMH 9491. JME SOS 2362, JME SOS 2364, JME SOS 2365, JME SOS 2458, JME SOS 2483, JME SOS 2496, JME SOS 2497, JME SOS 2886 (peels of scales), and many other specimens deposited at the JME. NHM 3672, NHM 3673a, NHM 37062, and NHM 37080. SHL, collection of H. Leich (Bochum, Germany) currently deposited in Tierpark und Fossilium Bochum (Bochum). SMNH P5683. TM 6651, TM 10307, and TM 10325. Additionally, one uncatalogued specimen belonging to U. Eller (Dümpelfeld, Germany) was included because of its excellent preservation.
Locality and geological time: Blumenberg, Eichstätt, Hofstetten, Kelheim, and Wintershof (Fig. 1) in Bavaria, southern Germany. Upper Jurassic, Tithonian (Meyer and Schmidt-Kaler, 1989, 1990; Schweigert, 2015). Ascalabos voithii has also been cited from Cerin (France; de SaintSeine, 1949; Wenz et al., 1993), which is interpreted as Kimmeridgian in age. This material is currently under revision. Description

A description of Ascalabos voithii can be found in Arratia (1997). Here, I only describe and illustrate additional information after of a re-study of the neotype and other specimens. I describe some characters that add new interpretations or a more complete understanding of certain structures. Some are compared with the structures in Ebertichthys n. gen.

General description: Ascalabos voithii has a head proportionally large, about $30 \%$ of standard length; however, the head in Ebertichthys is comparative larger, about $34 \%$ of SL. The diameter of the eye is large, 22 to $25 \%$ of the head length (Figs. 14b and 15b), whereas the eye in Ebertichthys ettlingensis is even larger, 34 to $36 \%$ of the head length. The insertion of the dorsal fin (Figs. 14a, 15a, and 16) is above the level of the insertion of the pelvic fins, about 52 to $58 \%$ of SL. In contrast, the insertion of the dorsal fin is posterior to that of the pelvic fins in Ebertichthys ettlingensis.

Cranial bones: The cranial bones are unornamented with the exception of the premaxilla, which bears some small, tubercle-like ornaments (Fig. 14c) covered with a thin layer of ganoine in the neotype. The braincase of the neotype is poorly preserved and does not add new information.

Circumorbital series: The supraorbital is incompletely preserved in most specimens or not preserved at all. It has an expanded anteroventral region, similar to that found in Ebertichthys ettlingensis. Infraorbital 1 is an elongate bone that joins with an elongate infraorbital 2 that is not as long as that of Ebertichthys (compare Figs. 3b, 4a, and 5 with Fig. 14b). Infraorbital 3 is a small bone at the posteroventral corner of the orbit (Fig. 14b). Because of its reduced size, a significant part of the quadrate is exposed. Although dorsoposterior infraorbitals 4 and 5 as the dorsal part of the preopercle are not preserved in the neotype, space left indicates that the region between the inner margin of infraorbitals 3-5 and the anterior margin of the preopercule was narrow.

Upper jaw: It contains the premaxilla, maxilla, and two supramaxillae (Fig. 14b), which are all preserved in the neotype. The re-study of the neotype confirms that the premaxilla has a short and small ascendent process as in the premaxilla in Ebertichthys n. gen. However, the articulatory anterior process of the maxilla is not as long as that in Ebertichthys, so that the posterior blade of the premaxilla is shorter. The maxilla is long and partially covers the anterior part of quadrate. The two supramaxillae of the neotype are very similar to that of Ebertichthys ettlingensis (compare Figs. 3b and 12b). Supramaxilla 2 is broadly expanded posteriorly, forming the main body of the bone. The anterodorsal process is very long and narrow. Supramaxilla 1 is elongate and ovoid-shaped. 


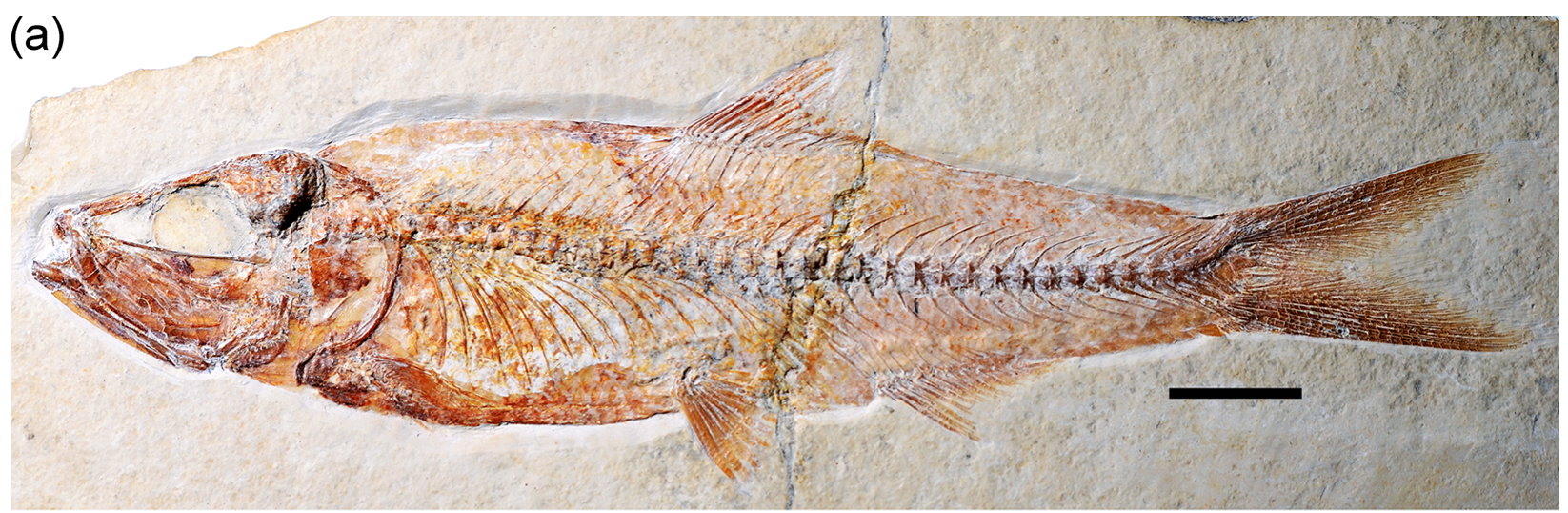

(b)

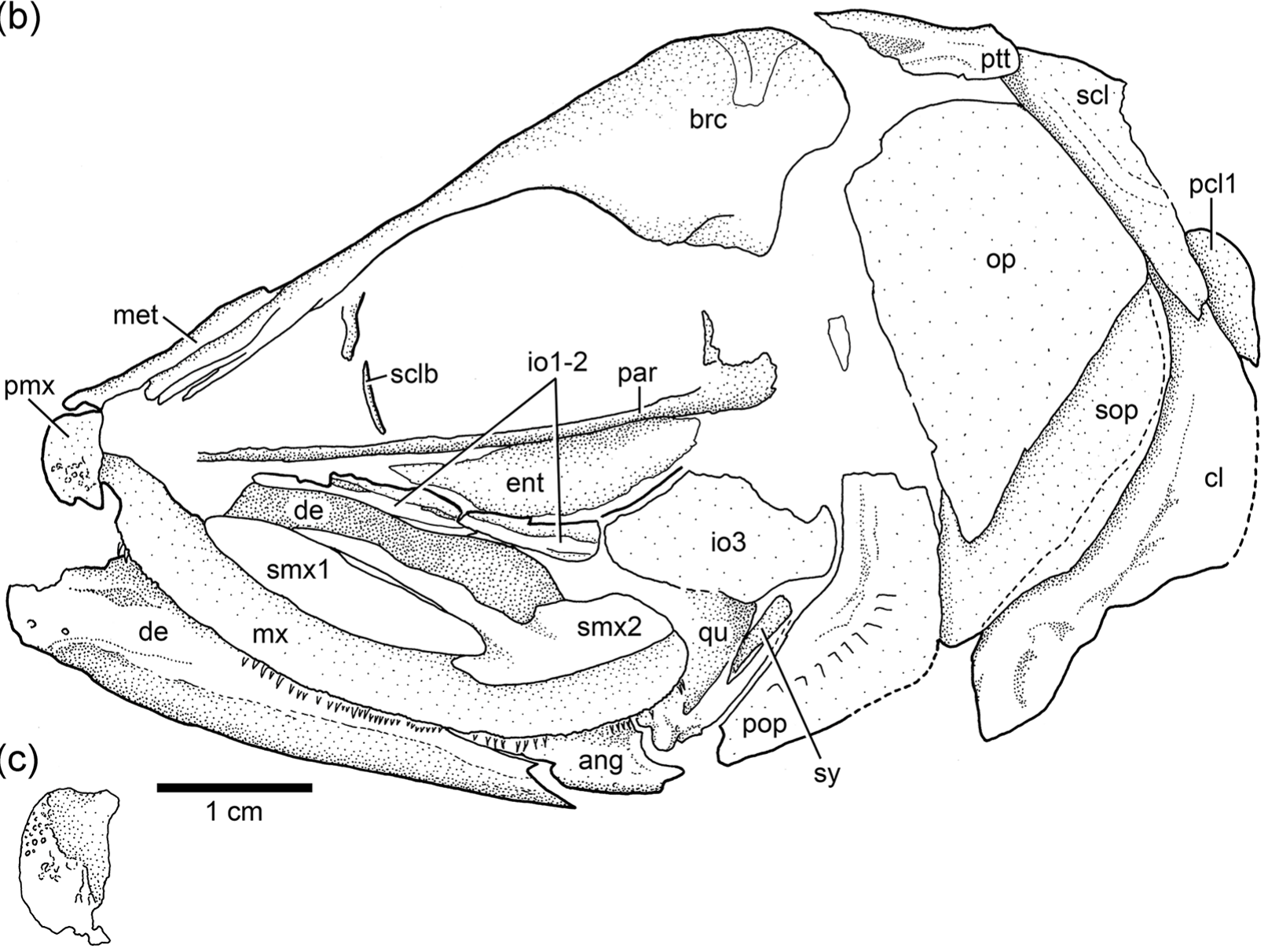

Figure 14. Ascalabos voithii (neotype, JME SOS 537). (a) Photograph of neotype in lateral view. Photograph courtesy of M. Ebert. Scale equals $1 \mathrm{~cm}$. (b) Cranium in lateral view and enlargement of premaxilla (c). Abbreviations: ang, angular; cl, cleithrum; de, dentary; ent, entopterygoid; io1-3, infraorbitals 1-3; mx, maxilla; par, parasphenoid; pcl1, postcleithrum 1; pmx, premaxilla; pop, preopercle; ptt, posttemporal; qu, quadrate; scl, supracleithrum; scl.b, broken sclerotic bone; smx1-2, supramaxillae 1-2; sop, subopercle; sy, symplectic.

Both supramaxillae cover the dorsal margin of the maxillary blade.

Lower jaw: The mandible (Fig. 14b) is strongly ossified, and although it is largely hidden by the maxilla and supramaxillae, the large and high coronoid process is visible in the neotype. The articulation of the mandible with the quadrate is placed at the posterior margin of the orbit in the neotype (specimen with almost closed mouth), which is in contrast to an anterior position in specimens with the mouth open. A "leptolepid" notch is present in the ascending dorsal margin 

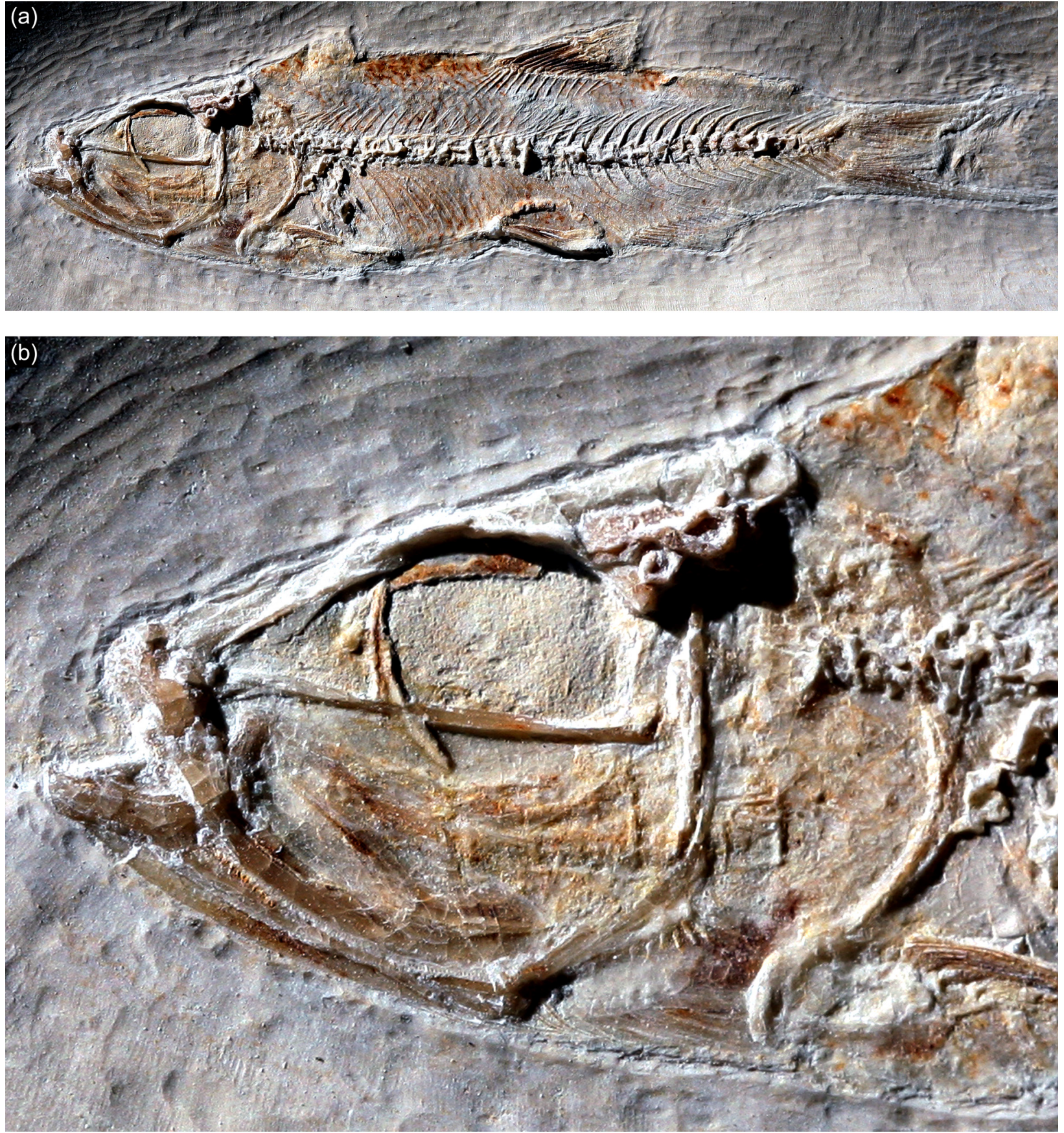

Figure 15. Ascalabos voithii from Schernfeld in the Eichstätt Basin. Uncatalogued specimen from U. Eller (Dümpelfeld). (a) Photograph of specimen in lateral view. (b) Enlargement of the head. Note the peculiar shape and distribution of the sensory tubules of the preopercular canal. Photographs courtesy of U. Eller.

of the dentary in specimen JME SOS 3228. This notch is not observed in the neotype, because the maxilla covers this region. The "leptolepid" notch is narrow and partially forms the anterior wall of the massive coronoid process.

Opercular bones: The preopercle (Figs. 14b and 15b) is incompletely preserved in the neotype, and it is probably somehow displaced. The important aspect to be noted is that the bone presents a slightly rounded bony flange at its anterior margin, similar to that in Ebertichthys n. gen. (compare Figs. $3 \mathrm{~b}$ and $4 \mathrm{a}$ with Fig. 14b). Since this feature has been observed only in a few specimens due to poor preservation, I have not considered it as a diagnostic character of the family, but this feature should be re-evaluated when more specimens of Ascalabos become available. The characteristic sen- 


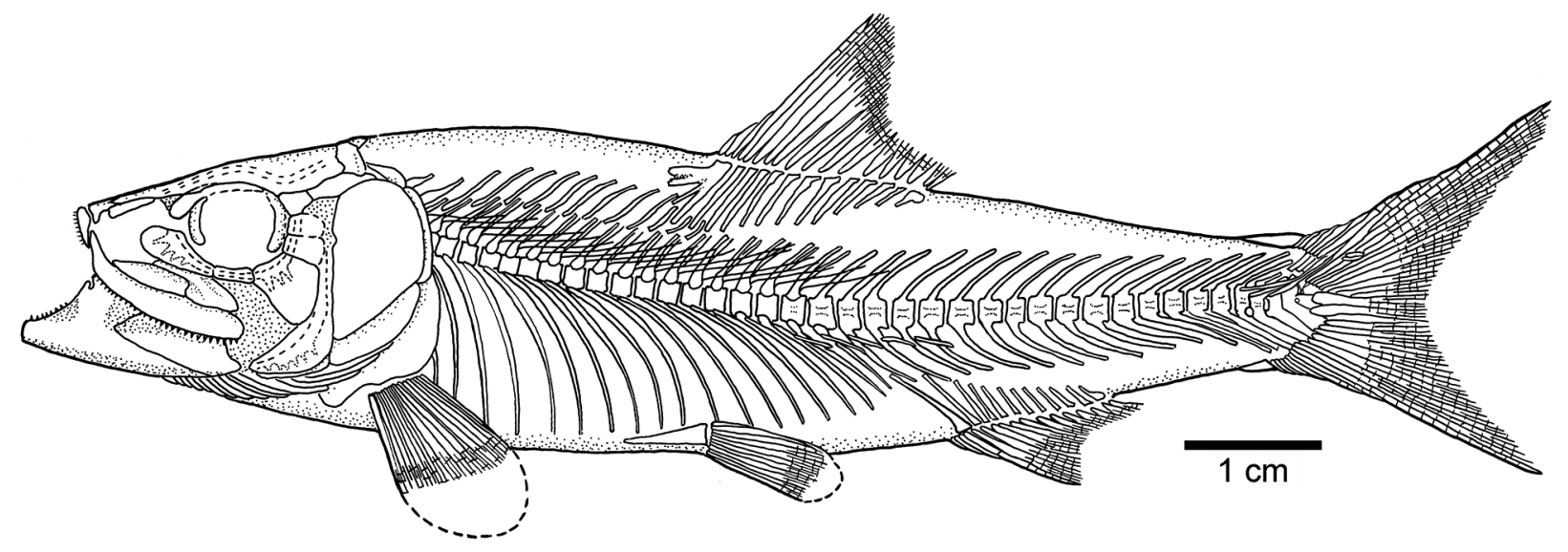

Figure 16. Ascalabos voithii. Restoration in lateral view, updated from Arratia (1997).

sory tubules of the preopercular sensory canal are nicely preserved in the neotype (Fig. 14b), as well as in an additional specimen illustrated in Fig. 15b.

Vertebral column: A long and prominent lateral crest (Fig. 17) characterizes the centra of the caudal region of the vertebral column in large specimens. The prominent crest is still present on the lateral surface of preural centrum 2 (Fig. 18). This is very different to the condition in Ebertichthys with smooth centra. Ascalabos may have from 34 to 39 vertebrae (commonly 36), whereas in Ebertichthys the number is commonly 38 or 39 . These represent the lowest counts among teleosts from the Solnhofen limestones (see Arratia and Schultze, 2015). There are 16 to 19 pairs of ribs (Fig. 16), whereas 18 or 19 pairs of ribs are present in Ebertichthys ettlingensis. A series of about 14 supraneurals extend between the occiput and below the first dorsal pterygiophores, whereas 16 supraneurals are commonly found in Ebertichthys, but they do not extend below the first dorsal pterygiophores.

The early formation of the centra of Ebertichthys ettlingensis (Fig. 9) is similar to that of Ascalabos voithii, so that the description above stands for both species. My observations (here and in Arratia, 1991, p. 257) and interpretations differ from those of Schaeffer and Patterson (1984), who interpreted the centra of young Tharsis, Ascalabos, and lycopterid osteoglossomorphs as diplospondylous, each formed by a precentrum and a postcentrum perichondrally ossified, and that the chordacentrum is then reabsorbed or suppressed in the middle of the centrum. These interpretations are not supported by my observations in young Tharsis, Ascalabos, and Ebertichthys n. gen.

Pelvic plate or basipterygium: The basipterygium of Ascalabos is characterized by its slightly triangular shape and its posterior expansion that has a short and sharp medial posterior process (Arratia, 1997, Fig. 19c). In contrast, the basipterygium of Ebertichthys ettlingensis lacks the posterior expansion, and a medial process has not been observed.
Dorsal and anal fins and their supports: The first dorsal pterygiophore is characteristically expanded and with a few anteroventral processes in Ebertichthys ettlingensis (Figs. 7 and 11a), and a similar pterygiophore (Fig. 16) is present in the neotype of Ascalabos. A first pterygiophore bearing only two processes (JME SOS 2886) and another partially broken one (HL 309) were illustrated for Ascalabos by Arratia (1997, Fig. 19a-b). Currently, I interpret these bones as partially incomplete. According to the evidence gathered here, the characteristic shape of the first dorsal pterygiophore is now proposed as a diagnostic feature of the new family Ascalaboidae.

The first anal pterygiophore is long, broadly expanded and almost rectangular in outline in Ebertichthys. In contrast, the pterygiophore is thinner and more rod-like in Ascalabos as well as in other Jurassic teleosts (see Arratia, 1981, 1997, 2000).

Caudal skeleton and fin: The caudal skeleton of the neotype confirms previous descriptions by Arratia (1991, 1997), but adds some new information about variability. While in some specimens the first two uroneurals extend anteriorly to the lateral surface of preural centrum 3 (Fig. 18), they reach preural centrum 2 in the neotype (Fig. 19). The neotype presents eight uroneurals, whereas in other specimens only seven have been observed, but this could be a result of poor preservation. The fourth uroneural is broken in the neotype, so that it is unclear whether it reached ural centrum $1+2$ or not, as it does in other specimens. Uroneurals 5 to 8 reduce in size caudally. The neural spine of preural centrum 2 is slightly shorter than that of preural centrum 3, which is broken distally. The neural arch of preural centrum 1 is incompletely preserved.

There is an incomplete series of epaxial basal fulcra, two segmented procurrent rays, one epaxial rudimentary ray, 19 principal caudal rays, three hypaxial procurrent rays, and five hypaxial basal fulcra in the neotype (Fig. 19). Fringing fulcra are absent. In contrast, other specimens have five or six 


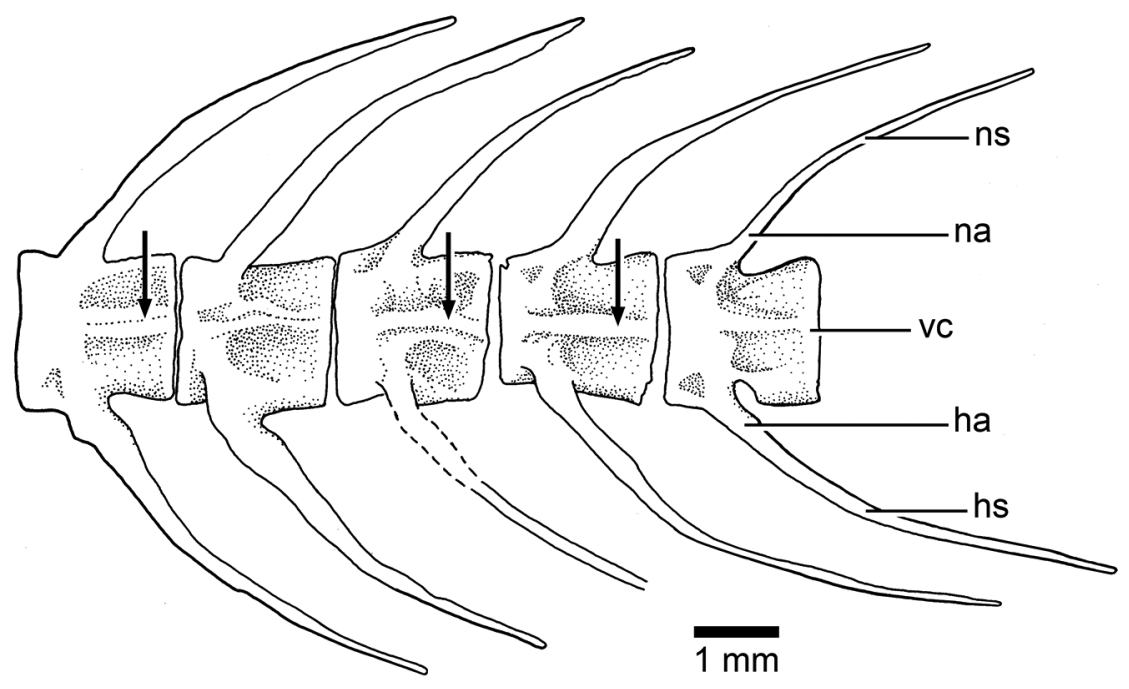

Figure 17. Ascalabos voithii (neotype, JME SOS 537). Midcaudal vertebrae illustrating the presence of a lateral crest and grooves on the lateral side of the vertebral centra. Arrows point to a lateral longitudinal crest. Abbreviations: na, neural arch; ns, neural spine; ha, haemal arch; hs, haemal spine; vc, vertebral centrum.

epaxial basal fulcra and seven hypaxial basal fulcra (Fig. 18). Dorsal and ventral scutes precede the epaxial and hypaxial basal fulcra, respectively.

Scales: The scales of Ascalabos are incompletely known, because it is difficult to observe isolated scales. The strongly imbricate scales are usually preserved in situ. They are slightly rectangular, with incomplete circuli in the anterior field and with transverse lines that do not completely cross the middle field of the scale. In contrast, Ebertichthys n. gen. has large, slightly oval scales (Fig. 6b) with few circuli in the anterior field. No transverse lines have been observed.

\section{Phylogenetic position of Ascalaboidae, n. fam.}

To assess the phylogenetic relationships of Ascalabos and Ebertichthys, I have performed a cladistic analysis of 42 advanced neopterygian taxa and 173 cranial, postcranial, and scale characters. The list of characters (Supplement 1) is from Arratia (2013) and includes additional taxon sampling (Ebertichthys) and seven new characters. The coding of 173 characters is presented in Supplement 2. Polarization of characters is based on outgroup comparison (five outgroups, including fossil and recent taxa).

A parsimony analysis was performed using PAUP 4.0 beta 10 (Swofford, 2000), using ACCTRAN characterstate optimization, a heuristic search using a random addition sequence with 500 replicates, and the three bisection and reconnection (TBR) branch-swapping algorithm. The parsimony analysis recovered one equally parsimonious tree of 463 steps (retention index $=0.7807$; consistency in$\operatorname{dex}=0.4462$; Fig. 20).
Figure 20 represents the only tree found. The topology of this tree differs from that of Arratia (2013) in the relationships among the outgroups and in Node $\mathrm{J}$ (now including Ebertichthys). Halecomorphs plus lepisosteiforms (outgroups) appeared as sisters to each other in Arratia (2013, fig. 95), whereas they appear now in a trichotomy with the teleosteomorph clade. For some characters with a few question marks, the parsimony analysis set forward some predictions or assumptions as potential synapomorphies of certain nodes. These assumptions are identified below. Characters supporting nodes are listed in the caption of Fig. 20. Here I only discuss the nodes representing the branching of Ascalaboidae $n$. fam.

Node J represents the branching of Ascalabos + Ebertichthys plus more advanced teleosts and is supported by 10 synapomorphies: toothless parasphenoid (Ch. 25[1]); canals for occipital arteries in basioccipital bone absent (Ch. 29[1]*); spiracular canal absent (Ch. 30[2]); no suborbital bone (Ch. 47[0]); one supraorbital bone (Ch. 49[1]); absence of a well-developed protruding lateral bony ridge extending along an elongate dentary that separates dental and splenial regions (Ch. 70[0]); midcaudal vertebral autocentra thick and sculptured (Ch. 97[1]); walls of midcaudal centra with cavities for adipose tissue (Ch. 98[1]*); notochord strongly constricted by the walls of the centra (Ch. 99[1]); and epaxial basal fulcra or epaxial procurrent rays in close proximity to neural spines, epurals, and posterior uroneurals (Ch. 145[1]).

The Node J1 corresponds to the branching of Ascalabos + Ebertichthys (Ascalaboidae n. fam.) and is supported by eight synapomorphies, four of which are interpreted as uniquely derived by the parsimony analysis: maxilla with external row of small conical teeth increasing slightly in 


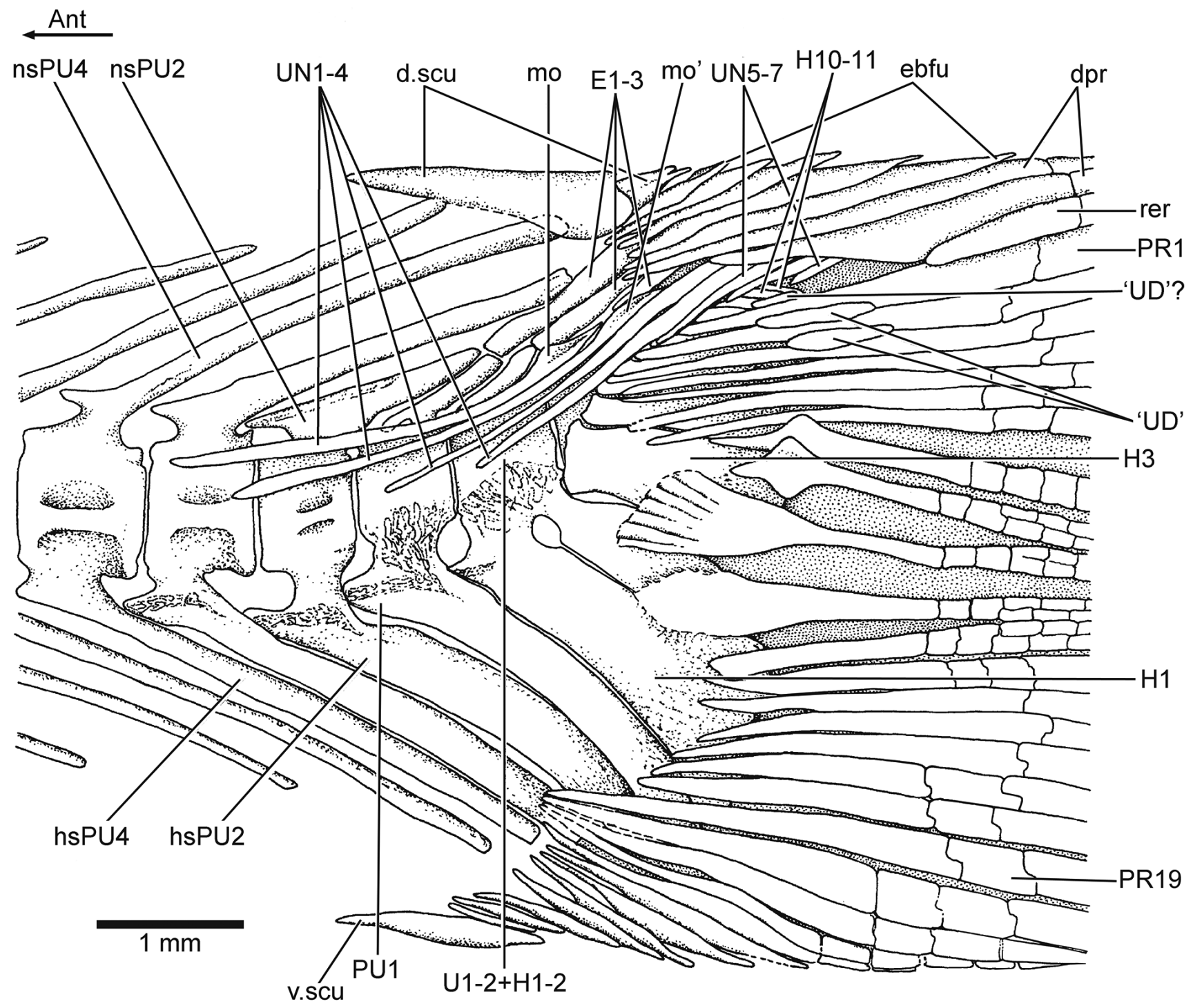

Figure 18. Ascalabos voithii. Caudal skeleton in lateral view slightly modified from Arratia (1997). Abbreviations: Ant, anterior; dpr, dorsal or epaxial procurrent rays; d.scu, dorsal caudal scute; ebfu, epaxial basal fulcra; E1-3, epurals 1-3; H1-11, hypurals 1-11; hsPU2, haemal spine of preural centrum 2; mo, membranous outgrowth on anterodorsal margin of first uroneural; mo', membranous outgrowth on anterodorsal margin of second uroneural; nsPU2-4, neural spine of preural centra 2-4; PR1,19, principal caudal rays 1, 19; rer, rudimentary fin ray; $\mathrm{U} 1+2+\mathrm{H} 1-2$, ural centrum $1+2$ (polyural terminology) fused with the bases of hypurals 1 and 2; 'UD', "urodermals"; UN1-7, uroneurals 1-7; v.scu., ventral caudal scute.

size posteriorly (Ch. 170[1]*); less than 40 vertebrae present (171[1]*); pseudo-diplospondyly present in the vertebral column of young growth stages (172[1]*); and first dorsal pterygiophore with three or more anteroventral processes, the first one broadly expanded (Ch. 173[1]*). Other synapomorphies supporting this node are the presence of an antorbital without antorbital sensory branch (Ch. 39[1]); median gular plate absent (93[1]); a compound first pectoral ray not fused with basal fulcra (Ch. 112[0]); hypaxial basal fulcra present (Ch. 144[0]); and cycloid scales with circuli crossed by trans- verse lines in the middle field (Ch. 157[1]). Although Ebertichthys is coded with questions marks for character 157 , the parsimony analysis predicts that transverse lines in the middle field of the scales cross the circuli. A similar prediction is inferred from the parsimony analysis concerning the composition of the first pectoral ray in Ascalabos that is coded with a question mark in the matrix.

The phylogenetic analysis interprets the following characters as autapomorphies of Ebertichthys ettlingensis n. gen. et sp.: midcaudal vertebral autocentra thick and smooth (Ch. 97[2]) 


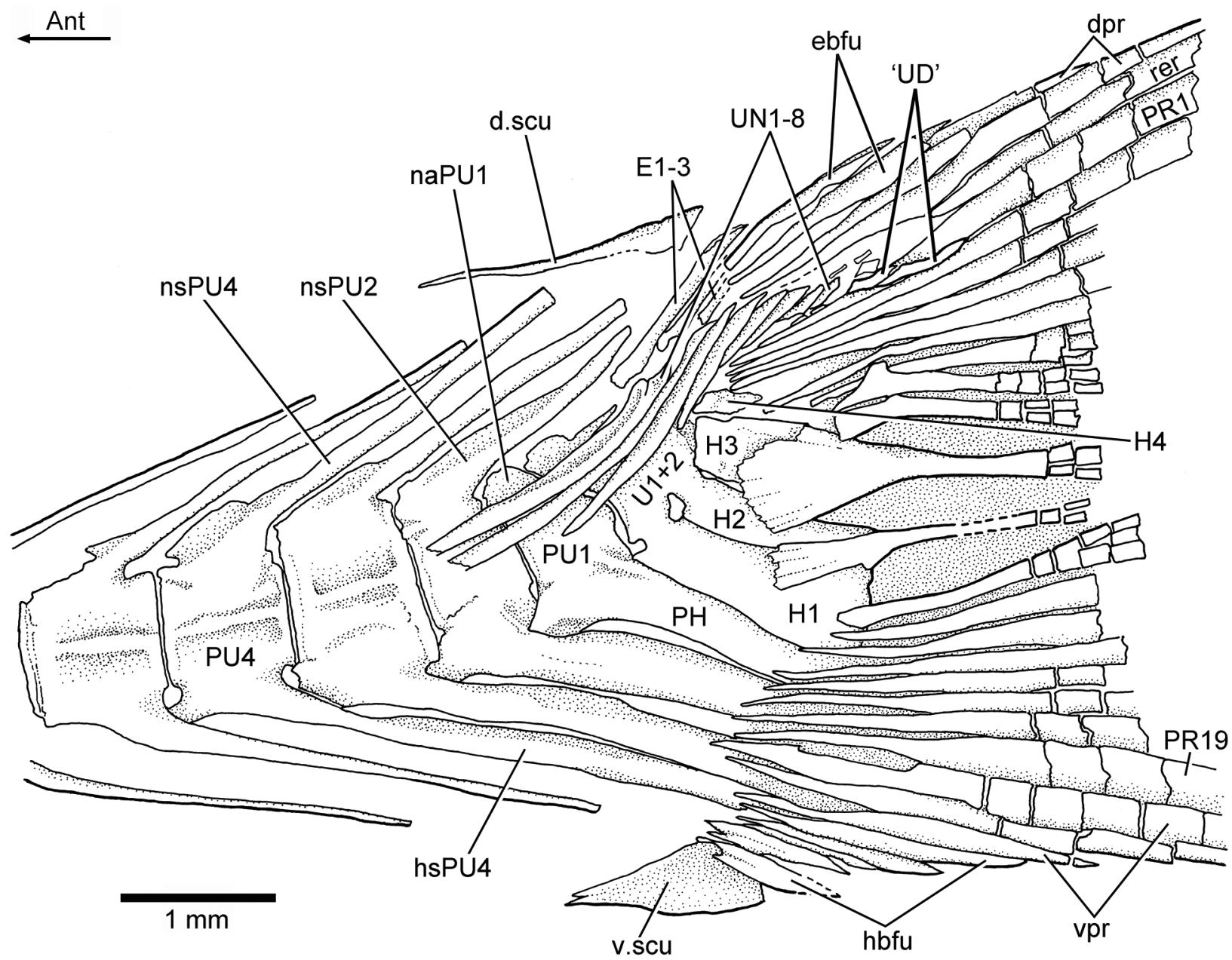

Figure 19. Ascalabos voithii. Caudal skeleton in lateral view with only two epaxial basal fulcra preserved (neotype, JME SOS 537). Abbreviations: Ant, anterior; d.scu, dorsal caudal scute; dpr, dorsal or epaxial procurrent rays; ebfu, epaxial basal fulcra; E1-3, epurals 1-3; H1-4, hypurals 1-4; hbfu, hypaxial basal fulcra; hsPU4, haemal spine of preural centrum 4; naPU1, neural arch of preural centrum 1; nsPU2-4, neural spine of preural centra 2-4; PH, parhypural; PU1,4, preural centrum 1, 4; rer, rudimentary fin ray; sc, dorsal and ventral caudal scutes; $\mathrm{U} 1+2$, ural centrum $1+2$ (polyural terminology) fused with the bases of hypurals 1 and 2; 'UD', "urodermals"; UN1-8, uroneurals 1-8; PR1-19, principal rays 1-19; vpr, ventral procurrent rays; v.scu, ventral caudal scute.

as opposed to the thick and sculptured centra typical in most Late Jurassic teleosts or the thin and smooth centra present in Leptolepides, and one tendon-bone "urodermal" (Ch. 152[2]), in contrast to two found in Ascalabos and other Late Jurassic teleosts.

The phylogenetic analysis interprets the following characters as autapomorphies of Ascalabos voithii: epaxial basal fulcra or epaxial procurrent rays in close proximity to epurals and posterior uroneurals (a reversal, Ch. 145[0]) and epaxial procurrent rays present (Ch. 146[1]).

\section{Final comments}

A few of the most primitive Late Jurassic teleosts from the Solnhofen limestones are known by single species that are not currently assigned to families, such as Ascalabos and Tharsis. Previously, and following the tradition of the time, both genera were assigned to the family Leptolepidae (e.g., Agassiz, 1843; Woodward, 1895) until the year 1974, when Nybelin removed Leptolepis voithii and Leptolepis $d u$ bius from the genus Leptolepis and assigned them to new genera, Ascalabos and Tharsis, respectively, within the family Leptolepidae. Later, both genera were removed from Leptolepidae and were left as incertae sedis among basal teleosts (Arratia, 1997, 1999). The present study demonstrates that Ascalabos voithii and Ebertichthys ettlingensis n. gen. et 


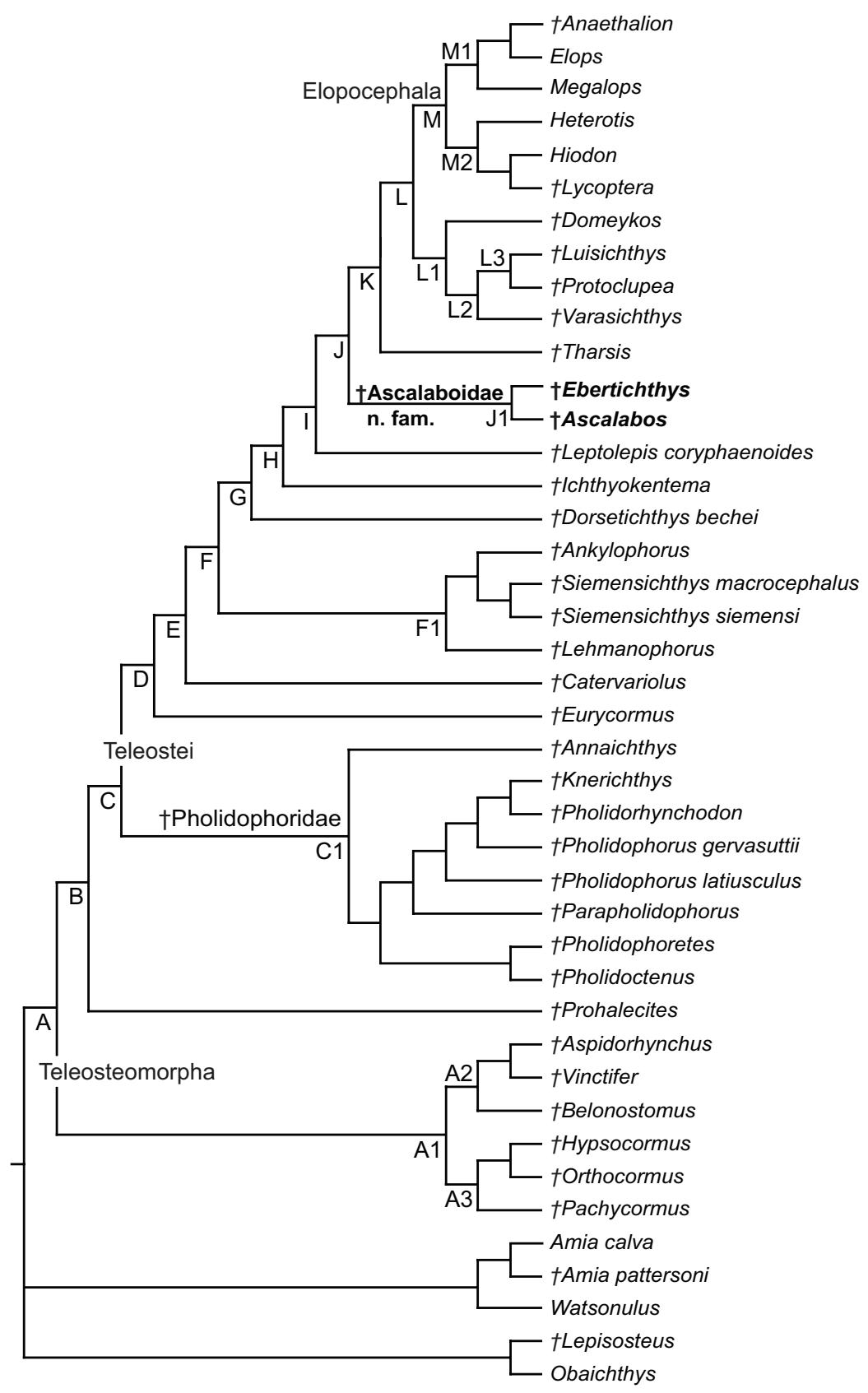

Figure 20. Hypothesis of phylogenetic relationships of the Late Jurassic Ascalabos and Ebertichthys n. gen. among the most primitive teleosts (highlighted in bold). Synapomorphies supporting the main nodes are listed below; for a complete list see Arratia (2013, 114118). Uniquely derived characters are identified with an asterisk [*]. See Supplement 1 for descriptions of characters listed below. Node A (teleosteomorphs or total-group teleost): 10[0]*, 24[1]*, 40[0]*, 47[2], 50[1], 94[0]*, 108[1], 112[1], 142[1]*, 164[1]*, 165[1]*, 168[1]*, and $169[1]^{*}$. Characters 142 and 164-168 are soft anatomical features that are unknown in fossils, but the parsimony analysis predicts that they were present at this phylogenetic level. Node B: 25[1], 34[1], 53[1], 55[1], 56[1], 59[1], 100[1], 109[1], 122[1], 125[1], and 162[1]. Node C: 47[1], 48[1], 59[2], 62[1], 63[1], 65[1], 69[1], 118[1], 148[2], and 153[1]. Node D: 78[1]*, 79[1], 102[1], 132[1], 150[1], and 151[1]. Node E: 13[1], 18[1], 56[0], 80[1]*, 96[1], 110[1], and 131[1]. Node F: 48[0], 66[1], 70[1], 82[1]*, 105[1], 108[0], 109[0], 127[1], and 129[1]. Node G: 3[1], 25[0], 42[1], 64[1], 68[1]*, 108[3], 111[1]*, and 162[0]. Node H: 28[1], 30[1], 32[1], 56[1], 67[1], 69[2], 83[1]*, $100[0], 103[1]^{*}, 121[1], 124[1], 140[1]$, and 149[1]*. Character 103[1] was incorrectly listed as a synapomorphy of node E in Arratia (2013). Node I: 50[2], 107[1], 114[1], 119[1], 120[1], 144[1], 148[3], 152[1], 155[1], and 156[2]. Node J (Ascalaboidae, n. fam.): 25[1], 29[1]*, 30[2], 47[0], 49[1], 70[0], 97[1], 98[1]*, 99[1], and 145[1]. Node K: 86[1], 134[1], and 143[1]. Node L: 31[1], 33[1], 113[1], 116[1], 122[0], 141[1], and 146[1]. Node M: 36[1], 63[0], 65[0], 86[0], 104[1], 117[2], 132[3], 143[0], 136[1], 150[0], and 152[0]. Node M1: 25[0], 51[1], 56[0], 128[1], 133[1], 135[1], and 152[2]. Node M2: 31[0], 38[1], 41[1], 45[1], 49[2], 50[0], 59[1], 75[1], 91[1], 93[1], 112[0], 118[0], $123[0], 129[2]$, and 148[0]. 
n. sp. belong together in a new family, Ascalaboidae, that is supported by numerous synapomorphies. Tharsis, a genus that is currently under study, is not assigned to a family yet. Specimens that were assigned to Leptolepis voithii from Cerin, France, by de Saint-Seine in 1949 (in part according to Nybelin, 1974) and to Anaethalion cirinensis by Gaudant in 1968 are not considered until they are re-studied. Specimens that have been preliminarily identified as Ascalaboslike from Wattendorf wait for study and clarification of their taxonomic status.

\section{The Supplement related to this article is available online at doi:10.5194/fr-19-31-2016-supplement.}

Acknowledgements. I thank the following individuals and institutions for permission to study material under their care: D. Berman (CM); H. Bjerring (SMNH); M. Kölbl-Ebert and G. Viohl (JME); A. Longbottom and the late C. Patterson (NHMUK). I especially thank H. Leich (Bochum) and U. Eller (Dümpelfeld) for permission to study some specimens belonging to their collections. Thanks to the following individuals and institutions for permission to study specimens included in the phylogenetic analysis: D. Berman (CM); H. Bjerring (SMNH); R. Böttcher (SMNS); D. Butt (UCLA); C. H. von Daniels (BGHan); W. Eschmeyer and D. Catania (CAS); W. L. Fink and D. Nelson (UMMZ); H. Furrer (PIMUZ); U. Göhlich (NHMW); L. Grande, W. Simpson, M. Westneat, and M. A. Rogers (FMNH); H. Jahnke (GOE); M. Kölbl-Ebert and G. Viohl (JME); the late K. Liem, K. Hartel, the late F. Jenkins, and J. Cundiff (UMCZ); M. Louette and the late G. Teugels (MRAC); D. Markle (OS); the late L. Martin and D. Miao (KUVP); J. McEacharan and M. Retzer (TCWC); W. Mette and W. Resch (Innsb.); A. Paganoni (MCSNB); L. Parenti and J. Williams (USNM); the late C. Patterson and A. Longbottom (NHMUK); T. Robins (UF); M. Röper (BMM-S); R. Rosenblatt (SIO); W. Saul (ANSP); F. J. Schwartz (UNC); A. Simons and V. Hirt (JFBM); D. Stacey and E. Holm (ROM); J. D. Stewart (formerly at LACM); M. Stiassny and B. Brown (AMNH); R. Stucky (DMNH); A. Tintori (University of Milan, Italy); P. Wellnhofer, O. W. M. Rauhut and M. Moser (BSPG); F. Westphal and the late R. Reif (GPIT); F. Witzmann (MB); E. O. Wiley and A. Bentley (KUNHM); J.-Y. Zhang and M. Zhu (IVVP); and Irene Zorn (GBA). Martin Ebert (JME) took the photographs of Ebertichthys n. gen., as well as of the neotype of Ascalabos. J.-P. Mendau (Berlin, Germany) prepared part of the final line illustrations based on my original drawings. T. J. Meehan prepared the electronic submission of all figures and revised the style of the manuscript. I thank Jürgen Kriwet and an anonymous reviewer for reviewing the manuscript and Hans-Peter Schultze for comments and suggestions.

Edited by: F. Witzmann

Reviewed by: J. Kriwet and another anonymous referee

\section{References}

Agassiz, L.: Recherches sur les Poissons Fossiles, 5 vols, Petit Pierre, Neuchâtel and Soleure, 1798 pp., 1833-1843.

Arratia, G.: Varasichthys ariasi n. gen. et sp. from the Upper Jurassic from Chile (Pisces, Teleostei, Varasichthyidae n. fam.), Palaeontographica Abt. A, 175, 107-139, 1981.

Arratia, G.: Anaethalion and similar teleosts (Actinopterygii, Pisces) from the Late Jurassic (Tithonian) of southern Germany and their relationships, Palaeontographica Abt. A, 200, 1-44, 1987a.

Arratia, G.: Orthogonikleithrus leichi n. gen., n. sp. (Pisces: Teleostei) from the Late Jurassic of Germany, Paläontol. Z., 61, 309-320, 1987b.

Arratia, G.: The caudal skeleton of Jurassic teleosts: A phylogenetic analysis, in: Early Vertebrates and Related Problems in Evolutionary Biology, edited by: Chang, M.-M., Liu, Y.-H., and Zhang, G.-R., Science Press, Beijing, 249-340, 1991.

Arratia, G.: Basal teleosts and teleostean phylogeny, Palaeo Ichthyol., 7, 1-168, 1997.

Arratia, G.: The monophyly of Teleostei and stem group teleosts, in: Mesozoic Fishes - Systematics and Fossil Record, edited by: Arratia, G. and Schultze, H.-P., Verlag Dr. F. Pfeil, München, 265-334, 1999.

Arratia, G.: Remarkable teleostean fishes from the Late Jurassic of southern Germany and their phylogenetic relationships, Foss. Rec., 3, 137-179, doi:10.5194/fr-3-137-2000, 2000.

Arratia, G.: Actinopterygian postcranial skeleton with special reference to the diversity of fin ray elements, and the problem of identifying homologies, in: Mesozoic Fishes 4 - Homology and Phylogeny, edited by: Arratia, G., Schultze, H.-P., and Wilson, M. V. H., Verlag Dr. F. Pfeil, München, 40-101, 2008.

Arratia, G.: Identifying patterns of diversity of the actinopterygian fulcra, Acta Zoologica, Stockholm, 90, 220-235, 2009.

Arratia, G.: Morphology, taxonomy, and phylogeny of Triassic pholidophorid fishes (Actinopterygii, Teleostei), J. Vertebr. Paleontol., 33(supplement 6, Memoir 13), 1-138, 2013.

Arratia, G. and Lambers, P.: The caudal skeleton of pachycormiform fishes: Parallel evolution?, in: Mesozoic Fishes - Systematics and Paleoecology, edited by: Arratia, G. and Viohl, G., Verlag Dr. F. Pfeil, München, 219-241, 1996.

Arratia, G. and Schultze, H.-P.: The urohyal: Development and homology within osteichthyans, J. Morphol., 203, 247-282, 1990.

Arratia, G. and Schultze, H.-P.: The palatoquadrate and its ossifications: Development and homology within osteichthyans, J. Morphol., 208, 1-81, 1991.

Arratia, G. and Schultze, H.-P.: Reevaluation of the caudal skeleton of certain actinopterygian fishes. III. Salmonidae. Homologization of caudal skeletal structures, J. Morphol., 214, 1-63, 1992.

Arratia, G. and Schultze, H.-P.: Outstanding features of a new Late Jurassic pachycormiform fish from the Kimmeridgian of Brunn, Germany and comments on current understanding of pachycormiforms, in: Mesozoic Fishes 5 - Global Diversity and Evolution, edited by: Arratia, G., Schultze, H.-P., and Wilson M. V. H., Verlag Dr. F. Pfeil, München, 87-120, 2013.

Arratia, G. and Schultze, H.-P.: Knochenfische i.e.S. (Teleostei), in: Solnhofen, ein Fenster in die Jurazeit, edited by: Arratia, G. Schultze, H.-P., Tischlinger, H., and Viohl, G., Verlag Dr. F. Pfeil, München, 389-409, 2015. 
Arratia, G. and Tischlinger, H.: The first record of Late Jurassic crossognathiform fishes from Europe and their phylogenetic importance for teleostean phylogeny, Foss. Rec., 13, 317-341, doi:10.5194/fr-13-317-2010, 2010.

Arratia, G., Schultze, H.-P., and Casciotta, J.: Vertebral column and associated elements in dipnoans and comparison with other fishes. Development and homology, J. Morphol., 250, 101-172, 2001.

Arratia, G., Schultze, H.-P., Tischlinger, H., and Viohl, G. (Eds.): Solnhofen, ein Fenster in die Jurazeit, Vols. 1 and 2, Verlag Dr. F. Pfeil, München, 2015.

Biese, W.: Über einige Pholidophoriden aus den lithographischen Schiefern Bayerns, Neues Jahrbuch für Mineralogie, Geol. Paläontol., 58, 501-100, 1927.

Brito, P. and Ebert, M.: A new aspidorhynchid fish (Teleostei: Aspidorhynchiformes) from the Upper Jurassic of Ettling, Solnhofen, Bavaria, Germany, C. R. Palevol., 8, 395-402, doi:10.1016/j.crpv.2008.12.003, 2009.

Cope, E. D.: Geology and Paleontology General Notes, Zittel's Manual of Palaeontology, Am. Natural., 21, 1014-1019, 1887.

de Blainville, H. D.: Sur les ichthyolites ou les poissons fossiles. Nouveau Dictionnaire d'Histoire Naturelle, Nouvelle Édition, 27, 310-395, 1818.

de Saint-Seine, P.: Les poissons des calcaires lithographiques de Cerin (Ain), Nouvelle Archive du Muséum d'Histoire naturelle, Lyon, 2, 1-357, 1949.

Eastman, C. R.: Catalog of the fossil fishes in the Carnegie Museum. Part 4. Descriptive catalog of the fossil fishes of the lithographic stone in Solnhofen, Bavaria, Memoirs of the Carnegie Museum, 6, 389-423, 1914.

Ebert, M. and Kölbl, M.: Räuber-Beute-Beziehungen bei Orthogonikliethrus hoelli Arratia 1997, Archaeopteryx, 26, 11-18, 2008.

Ebert, M. and Kölbl-Ebert, M.: Forschungsgrabung Ettling: Grabungssaison 2011, Archaeopteryx, 29, 41-52, 2011.

Ebert, M., Kölbl-Ebert, M., and Lane, M.: Fauna and predator-prey relationship of Ettling, an actinopterygian fish dominated Konservat-Lagerstätte from the Late Jurassic of Southern Germany, PLoS ONE, 10, e0116140, doi:10.1371/journal.pone.0116140, 2015.

Gaudant, J.: Contribution à une révision des Anaethalion de Cérin (Ain.), Bulletin du Bureau de Recherches Géologiques et Minières, 4, 95-115, 1968.

Giebel, C. G.: Fauna der Vorwelt, mit steter Berücksichtigung der lebenden Tiere. Erster Band: Wirbelthiere. Dritte Abtheilung: Fische, Brockhaus, Leipzig, 1-467, 1848.

Graf zu Münster, G.: Mittheilungen, an Professor Bronn gerichtet, Neues Jahrbuch für Mineralogie, Geognosie, Geologie und Petrefaktenkunde, 1834, 538-542, 1834.

Graf zu Münster, G.: Über einige Versteinerungen in den lithographischen Schiefern von Solnhofen, Neues Jahrbuch für Mineralogie, Geognosie, Geologie und Petrefaktenkunde, 1839, 677-682, 1839a.

Graf zu Münster, G.: Ascalabos voithii, Beiträge zur PetrefactenKunde, 2, 112-114, 1839b.

Graf zu Münster, G.: Beiträge zur Kenntniss einiger neuen seltenen Versteinerungen aus den lithographischen Schiefern in Baiern, Neues Jahrbuch für Mineralogie, Geognosie, Geologie und Petrefaktenkunde, 1842, 35-64, 1842.
Grande, L. and Bemis, W. E.: A comprehensive phylogenetic study of amiid fishes (Amiidae) based on comparative skeletal anatomy. An empirical search for interconnected patterns of natural history, Society of Vertebrate Paleontology, Memoir 4, 1690, 1998.

Jollie, M.: Chordate Morphology, Reinhold Publishing Co., New York, 1962.

Knorr, G. W.: Sammlung von Merckwürdigkeiten der Natur- und Alterthümern der Erdbodens welche petreficirte Cörper enthält, Thl. I, 1, Abschnitt, A. Bieling, Nürnberg, 1-187, 1755.

Lambers, P.: On the ichthyofauna of the Solnhofen Lithographic Limestone (Upper Jurassic, Germany, Unpublished Doctoral Thesis, Rijksuniversiteit Groningen, the Netherlands, 1-366, 1992.

Meyer, R. and Schmidt-Kaler, H.: Paläogeographischer Atlas des süddeutschen Oberjura (Malm), Geol. Jahrbücher A, 225, 3-77, 1989.

Meyer, R. and Schmidt-Kaler, H.: Wanderungen in die Erdgeschichte, (1) Treuchtlingen - Solnhofen - Mörnsheim, Dollnstein, Verlag Dr. F. Pfeil, München, 1990.

Nybelin, O.: Zur Morphologie und Terminologie des Schwanzskelettes der Actinopterygier, Arkiv för Zoologi, 15, 485-516, 1963.

Nybelin, O.: Versuch einer taxonomischen Revision der jurassischen Fisch-Gattung Thrissops Agassiz, Göteborgs kungliga vetenskaps-och vitterhets Samhälles Handligar, Ser. B, 9, 1-44, 1964.

Nybelin, O.: Versuch einer taxonomischen Revision der Anaethalion-Arten des Weissjura Deutschlands, Acta Regiae Societatis Scientiarum et Litterarum Gothoburgensis, Zoologica, 2, 1-53, 1967.

Nybelin, O.: A revision of the leptolepid fishes, Acta Regiae Societatis Scientiarum et Litterarum Gothoburgensis, Zoologica, 9, 1-202, 1974.

Patterson, C. and Rosen, D. E.: Review of ichthyodectiform and other Mesozoic teleost fishes and the theory and practice of classifying fossils, Bull. Am. Museum Nat. Hist., 158, 81-172, 1977.

Schaeffer, B. and Patterson, C.: Jurassic fishes from the western United States, with comments on Jurassic fish distribution, Am. Museum Novit., 2796, 1-86, 1984.

Schultze, H.-P.: Morphologische und histologische Untersuchungen an den Schuppen mesozoischer Actinopterygier (Übergang von Ganoid- zu Rundschuppen), Neues Jahrbuch für Geologie und Paläontologie, Abhandlungen 126, 232-312, 1966.

Schultze, H.-P.: The scales of Mesozoic actinopterygians, in: Mesozoic Fishes - Systematics and Paleoecology, edited by: Arratia, G. and Viohl, G., Verlag Dr. F. Pfeil, München, 83-93, 1996.

Schultze, H.-P.: Nomenclature and homologization of cranial bones in actinopterygians, in: Mesozoic Fishes 4 - Homology and Phylogeny, edited by: Arratia, G., Schultze, H.-P., and Wilson, M. V. H., Verlag Dr. F. Pfeil, München, 23-48, 2008.

Schultze, H.-P.: Liste der Fossilien, in: Solnhofen, ein Frenster in die Jurazeit, edited by: Arratia, G., Schultze, H.-P., Tischlinger, H., and Viohl, G., Verlag Dr. F. Pfeil, München, 560-672, 2015.

Schultze, H.-P. and Arratia, G.: Reevaluation of the caudal skeleton of actinopterygian fishes. I. Lepisosteus and Amia, J. Morphol., 190, 215-241, 1986. 
Schultze, H.-P. and Arratia, G.: Reevaluation of the caudal skeleton of some actinopterygian fishes. II. Hiodon, Elops and Albula, J. Morphol., 195, 257-303, 1988.

Schultze, H.-P. and Arratia, G.: The composition of the caudal skeleton of teleosts (Actinopterygii, Osteichthyes), Zool. J. Linnean Soc. Lond., 97, 189-231, 1989.

Schultze, H.-P. and Arratia, G.: The caudal skeleton of basal teleosts, its conventions, and some of its major evolutionary novelties in a temporal dimension, in: Mesozoic Fishes 5 - Global Diversity and Evolution, edited by: Arratia, G., Schultze, H.-P., and Wilson, M. V. H., Verlag Dr. F. Pfeil, München, 187-246, 2013.

Schweigert, G.: Biostratigraphie der Plattenkalke der Südlichen Frankenalb, in: Solnhofen, ein Frenster in die Jurazeit, edited by: Arratia, G., Schultze, H.-P., Tischlinger, H., and Viohl, G., Verlag Dr. F. Pfeil, München, 63-66, 2015.

Swofford, D. L.: PAUP*: Phylogenetic Analysis Using Parsimony (* and other methods), Version 4.0 Beta, Sinauer Associates, Sunderland, Massachusetts, 2000.

Taverne, L.: Sur Leptolepis (Ascalabos) voithi (Münster, G. 1839), téléostéen fossile du Jurassique supérieur de 1' Europe, et ses affinités systématiques, Biologisch Jaarboek Dodonaea, 43, 233 245, 1975a.

Taverne, L.: Considérations sur la position systématique des genres fossiles Leptolepis et Allothrissops au sein des Téléostéens primitives et sur l'origine et le polyphylétisme des Poissons Téléostéens, Bulletin de la Classe des Sciences, Académie Royale de Belgique, 5 série, LXX, 335-371, 1975 b.

Taverne, L.: Ostéologie et affinités systématiques de Leptolepides sprattiformis (Pisces, Teleostei) du Jurasique supérieur de l'Europe, Annales de la Société Royale Zoologique, Belgique, 100, 7-28, 1981.

Tischlinger, H. and Viohl, G.: Sammler, Sammlungen, und Forscher, in: Solnhofen, ein Fenster in die Jurazeit, edited by: Arratia, G., Schultze, H.-P., Tischlinger, H., and Viohl, G., Verlag Dr. F. Pfeil, München, 41-54, 2015.
Vetter, B.: Die Fische aus dem lithographischen Schiefer im Dresdener Museum, Mittheilungen aus dem königlich mineralogischgeologischen und praehistorischen Museum in Dresden, 4, 1$118,1881$.

Viohl, G.: The paleoenvironment of the Late Jurassic fishes from the southern Franconian Alb (Bavaria, Germany), in: Mesozoic Fishes - Systematics and Paleoecology, edited by: Arratia, G and Viohl, G., Verlag Dr. F. Pfeil, München, 513-528, 1996.

Wagner, J. A.: Vergleichung der urweltlichen Fauna des lithographischen Schiefers von Cerin mit den gleichnamigen Ablagerungen im fränkischen Jura, Gelehrter Anzeiger der königlich bayerischen Akademie der Wissenschaften, 48, 390-412, 1861.

Wagner, J. A.: Monographie des fossilen Fische aus dem lithographischen Schiefer Bayerns, Zweite Abtheilung, Abhandlungen der der königlich bayerischen Akademie der Wissenschaften, mathematisch-physikalische Klasse, 9, 612-748, 1863.

Wenz, S., Bernier, P., Barale, G., Bourseau, J. P., Buffetaut, E., Gaillard, C., and Gall, J. C.: L' ichthyofaune des calcaires lithographiques du Kimméridgien supérieur de Cerin (Ain, France), Geobios, M. S., 16, 61-70, 1993.

Westoll, T. S.: The origin of the tetrapods, Biol. Rev., 18, 78-98, 1943.

Weitzel, K.: Pachythrissops microlepidotus n. sp., ein neuer Leptolepide aus den Solnhofer Schiefern, Paläontol. Z., 15, 22-30, 1933.

Woodward, A. S.: Catalogue of the Fossil Fishes in the British Museum (Natural History). Part III, 1-544, Trustees of the British Museum of Natural History, London, 1895. 